Provided for non-commercial research and education use. Not for reproduction, distribution or commercial use.

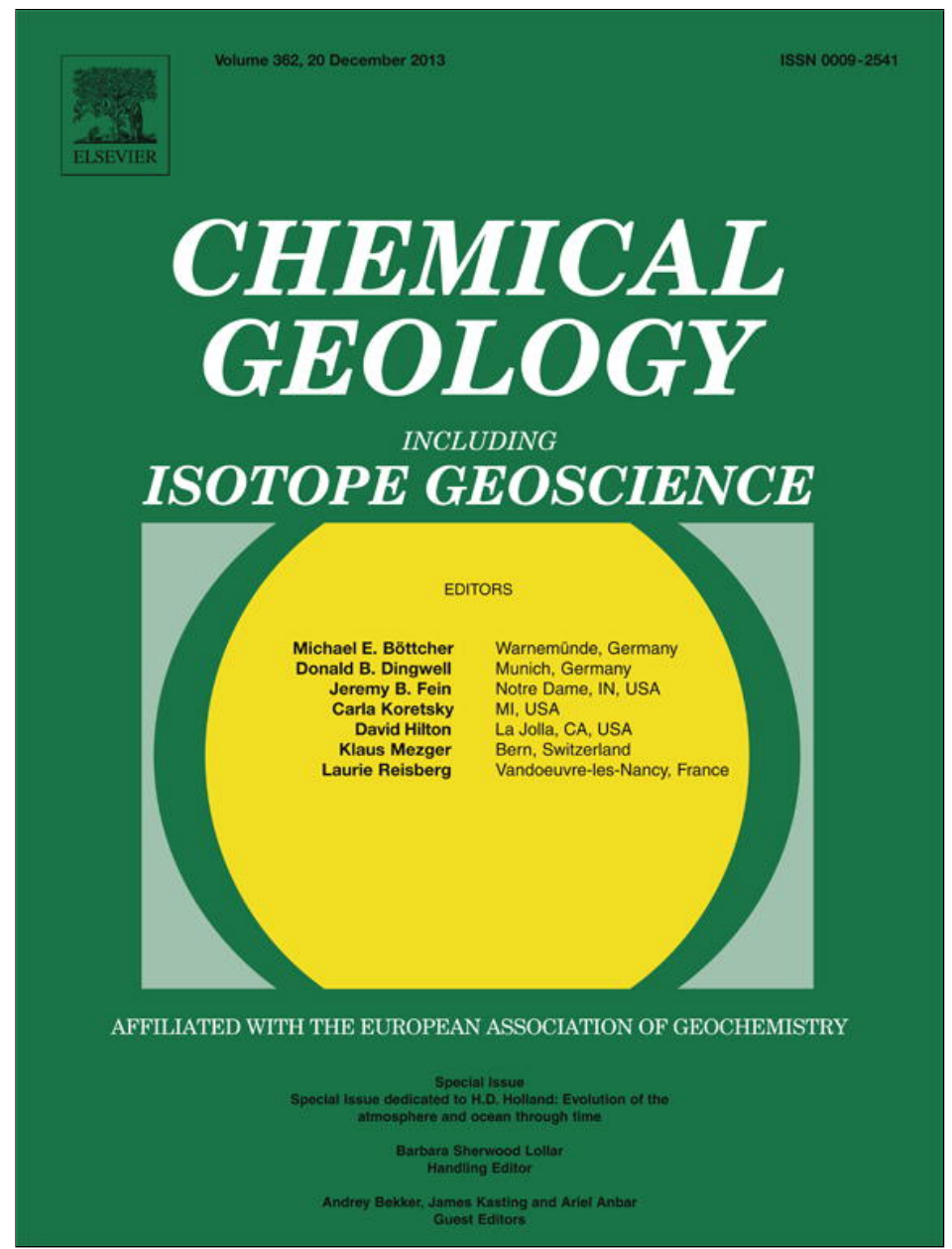

This article appeared in a journal published by Elsevier. The attached copy is furnished to the author for internal non-commercial research and education use, including for instruction at the authors institution and sharing with colleagues.

Other uses, including reproduction and distribution, or selling or licensing copies, or posting to personal, institutional or third party websites are prohibited.

In most cases authors are permitted to post their version of the article (e.g. in Word or Tex form) to their personal website or institutional repository. Authors requiring further information regarding Elsevier's archiving and manuscript policies are encouraged to visit:

http://www.elsevier.com/authorsrights 


\title{
The stratigraphic relationship between the Shuram carbon isotope excursion, the oxygenation of Neoproterozoic oceans, and the first appearance of the Ediacara biota and bilaterian trace fossils in northwestern Canada
}

\author{
Francis A. Macdonald ${ }^{a}$,*, Justin V. Strauss a , Erik A. Sperling a ${ }^{a}$ Galen P. Halverson ${ }^{b}$, Guy M. Narbonne ${ }^{c}$, \\ David T. Johnston a , Marcus Kunzmann ${ }^{\text {b }}$, Daniel P. Schrag a , John A. Higgins ${ }^{\text {d }}$ \\ a Department of Earth and Planetary Sciences, Harvard University, 20 Oxford St., Cambridge, MA 02138, United States \\ b Department of Earth and Planetary Sciences/GEOTOP, McGill University, Montreal, QC H3A 2T5, Canada \\ c Department of Geological Sciences and Geological Engineering, Queen's University, Kingston, Ontario K7L 3N6, Canada \\ d Princeton University, Guyot Hall, Princeton, NJ 08544, United States
}

\section{A R T I C L E I N F O}

\section{Article history:}

Accepted 27 May 2013

Available online 7 June 2013

\section{Keywords:}

Ediacaran

Shuram

Windermere

Carbon-isotope

Trace fossils

Fe-speciation

\begin{abstract}
A B S T R A C T
A mechanistic understanding of relationships between global glaciation, a putative second rise in atmospheric oxygen, the Shuram carbon isotope excursion, and the appearance of Ediacaran-type fossil impressions and bioturbation is dependent on the construction of accurate geological records through regional stratigraphic correlations. Here we integrate chemo-, litho-, and sequence-stratigraphy of fossiliferous Ediacaran strata in northwestern Canada. These data demonstrate that the FAD of Ediacara-type fossil impressions in northwestern Canada occur within a lowstand systems tract and above a major sequence boundary in the informally named June beds, not in the early Ediacaran Sheepbed Formation from which they were previously reported. This distinction is substantiated by $\delta^{13} \mathrm{C}_{\mathrm{carb}}$ chemostratigraphy of the Sheepbed carbonate, which overlies the Sheepbed Formation, and the Gametrail Formation, which overlies the June beds. The Sheepbed carbonate hosts heavy $\delta^{13} C_{\text {carb }}$ values whereas the Gametrail Formation contains a large $\delta^{13} C_{\text {carb }}$ excursion, which we correlate with the globally recognized Shuram excursion. Stratigraphically above the Gametrail excursion, the first bilaterian burrows are present in the basal Blueflower Formation. Together, these data allow us to construct an age model for Ediacaran strata in northwestern Canada and conclude that a purported shift in Fe speciation in the Sheepbed Formation significantly predates the shift recorded above the ca. $582 \mathrm{Ma}$ Gaskiers glaciation in Newfoundland and the first appearance of Ediacaran biota.

The Gametrail excursion shares many characteristics with Shuram negative $\delta^{13} \mathrm{C}_{\text {carb }}$ excursion: 1) $\delta^{13} \mathrm{C}_{\text {carb }}$ and $\delta^{18} \mathrm{O}_{\text {carb }}$ covary; 2) $\delta^{13} \mathrm{C}_{\text {carb }}$ and $\delta^{13} \mathrm{C}_{\text {org }}$ do not covary; 3 ) the excursion is developed during a transgressive systems tract and recovers in an highstand systems tract; and 4) values in some sections are well below mantle $\delta^{13} \mathrm{C}$ input values but are variable between sections. We relate regional lateral variability in the magnitude and character of this excursion to condensation and diachronous deposition during the transgression and local authigenic carbonate production. In light of these observations, we explore a variety of models for the genesis of the Shuram excursion and suggest that the location and amount of authigenic carbonate production played a role in the excursion.
\end{abstract}

(c) 2013 Elsevier B.V. All rights reserved.

\section{Introduction}

Ediacaran strata are exposed in the Ogilvie, Wernecke, and Mackenzie Mountains of northwestern Canada. These mixed carbonatesiliciclastic successions host a rich paleontological record characterized by abundant Ediacara-type fossil impressions and bilaterian trace fossils (e.g. Narbonne and Hofmann, 1987; Hofmann et al. 1990; Narbonne and Aitken, 1990; Narbonne, 1994; Narbonne and

\footnotetext{
* Corresponding author.

E-mail address: fmacdon@fas.harvard.edu (F.A. Macdonald).
}

Aitken, 1995; MacNaughton and Narbonne, 1999); as such, these deposits provide an ideal natural laboratory to test proposed models for the evolution of late Proterozoic marine biogeochemistry. However, unlike other Ediacaran successions, it has been suggested that the Shuram negative carbon isotope excursion - a critical benchmark for understanding Ediacaran geochemical cycling and temporal constraints - is not present in northwestern Canada (Derry, 2010). The apparent absence of this anomaly may reflect the degree to which the event is global or confounded by regional isotopic variability (e.g. Li et al., 1999; Xiao et al., 2004; Jiang et al., 2007), locally truncated within unconformities (MacNaughton et al., 2000, 2008), or not 
recognized due to the reconnaissance level of previous chemostratigraphic studies in the region (Narbonne et al., 1994; Kaufman et al., 1997). Mapping the global distribution and variability of the Shuram excursion is critical to understanding its origin and significance, in particular because it has been related to the oxygenation of the deep ocean (e.g. Fike et al., 2006). If the excursion was driven by an oxygenation event, we might expect intimate stratigraphic relationships between the Shuram excursion, oxygenation of the water column as

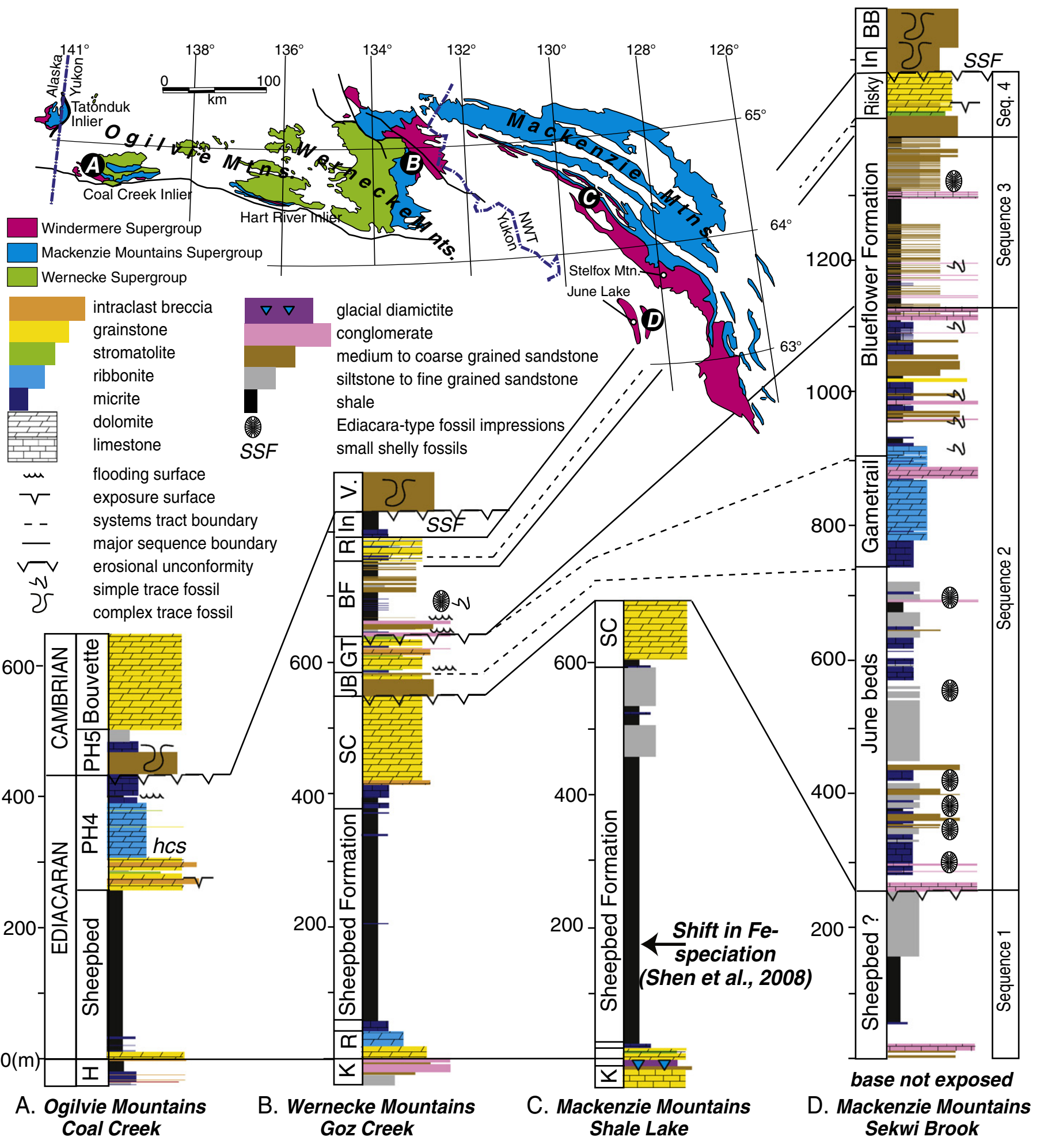

Fig. 1. Schematic Ediacaran stratigraphy across northwestern Canada with inset map documenting distribution of Proterozoic strata in the Ogilvie, Wernecke and Mackenzie Mountains (modified from Abbott, 1997). Locations A, B, C, and D on the map refer to the different key localities shown in the schematic stratigraphic sections below and discussed at length in the text. $\mathrm{H}=$ Hay Creek Group, $\mathrm{K}=$ Keele Formation, $\mathrm{R}=$ Ravensthroat Formation, SC $=$ Sheepbed carbonate of the Sheepbed Formation, JB $=$ June beds, BF $=$ Blueflower Formation, GT = Gametrail Formation, $\mathrm{R}=$ Risky Formation, In = Ingta Formation, $\mathrm{BB}=$ Backbone Ranges Formation, $\mathrm{V}=\mathrm{Vampire}$ Formation. 
measured by proxies like Fe speciation, and the first appearance and/or proliferation of bilaterians with high metabolic demands.

Stratigraphically-constrained Fe speciation analyses in Newfoundland have related the ca. $582 \mathrm{Ma}$ Gaskiers glaciation to Ediacaran oxygenation and the subsequent appearance of the Ediacaran biota (Canfield et al., 2007). Similarly, previous Fe-speciation studies in northwestern Canada have reported shifts in Fe speciation data in the Ediacaran Sheepbed Formation, attributing this to a rise in oxygen coincident with the first appearance datum (FAD) of Ediacaran-type fossils (Shen et al., 2008). However, the proposed linkage between the FAD of Ediacaran-type fossils in northwestern Canada and the purported oxygenation event is only as reliable as the stratigraphic correlations between outer shelf deposits in the central Mackenzie Mountains (site of Fe-speciation study: Shen et al., 2008) and distal fossiliferous slope sections $\sim 130 \mathrm{~km}$ to the south near Sekwi Brook (Fig. 1). Indeed, because it is rare for any single section to record a complete and continuous geochemical and paleontological record, regional stratigraphic correlations are necessary to construct a composite record within a basin. Large lateral facies changes, the lack of continuous exposure, and overlapping unconformities have confounded previous correlation schemes based on lithostratigraphy (Aitken, 1984, 1989; MacNaughton et al., 2000), and robust correlations between these localities is required to link geochemical and paleontological data in a mechanistic scenario.

Here we aim to synthesize paleontological and geochemical records of the Ediacaran Period from northwestern Canada using an integrated approach that includes geological mapping, sequence stratigraphic analysis, and carbon isotope chemostratigraphy. We focus our descriptions on four localities: Shale Lake (also referred to as Palmer Lake) of the central Mackenzie Mountains, Sekwi Brook and the nearby June Lake of the southwestern Mackenzie Mountains, Goz Creek of the Wernecke Mountains, and the Coal Creek inlier of the Ogilvie Mountains (Fig. 1). Through this revised sequence stratigraphic framework we are able to construct a new age model for Ediacaran strata in northwestern Canada, revisit the purported evidence for oxygenation of the Ediacaran oceans, weigh various models for the Shuram excursion, and better assess the relationships between geochemical changes in the ocean and biological evolution.

\section{Geological setting}

Ediacaran strata in northwestern Canada are discontinuously exposed in Proterozoic erosional inliers. These strata were previously portrayed as deposits that formed along an open, continental shelf-

Table 1

Correlation chart of stratigraphic nomenclature that has been used in previous studies of the Ediacaran informal Upper group of northwestern Canada. The references for each region are provided in the Table.

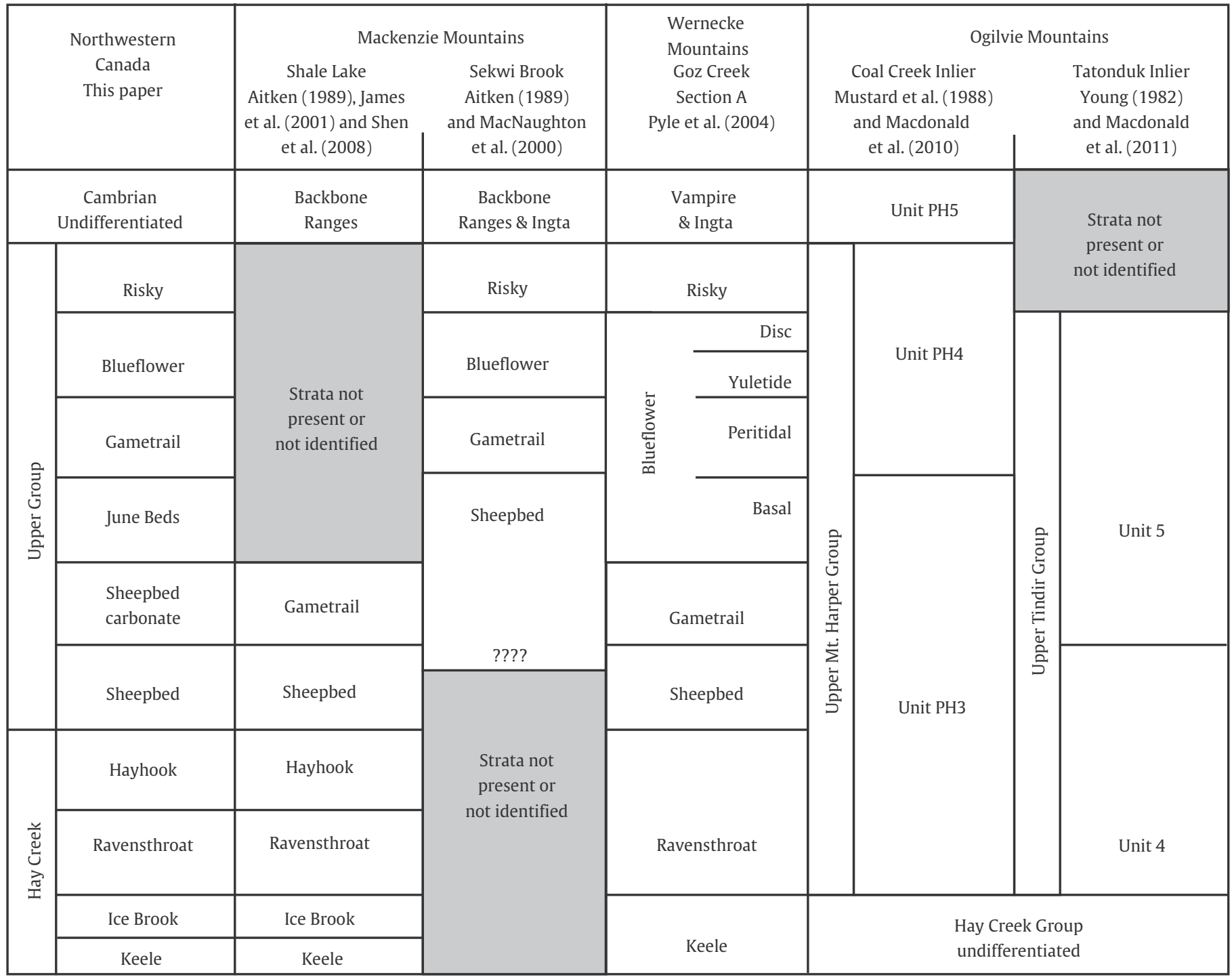




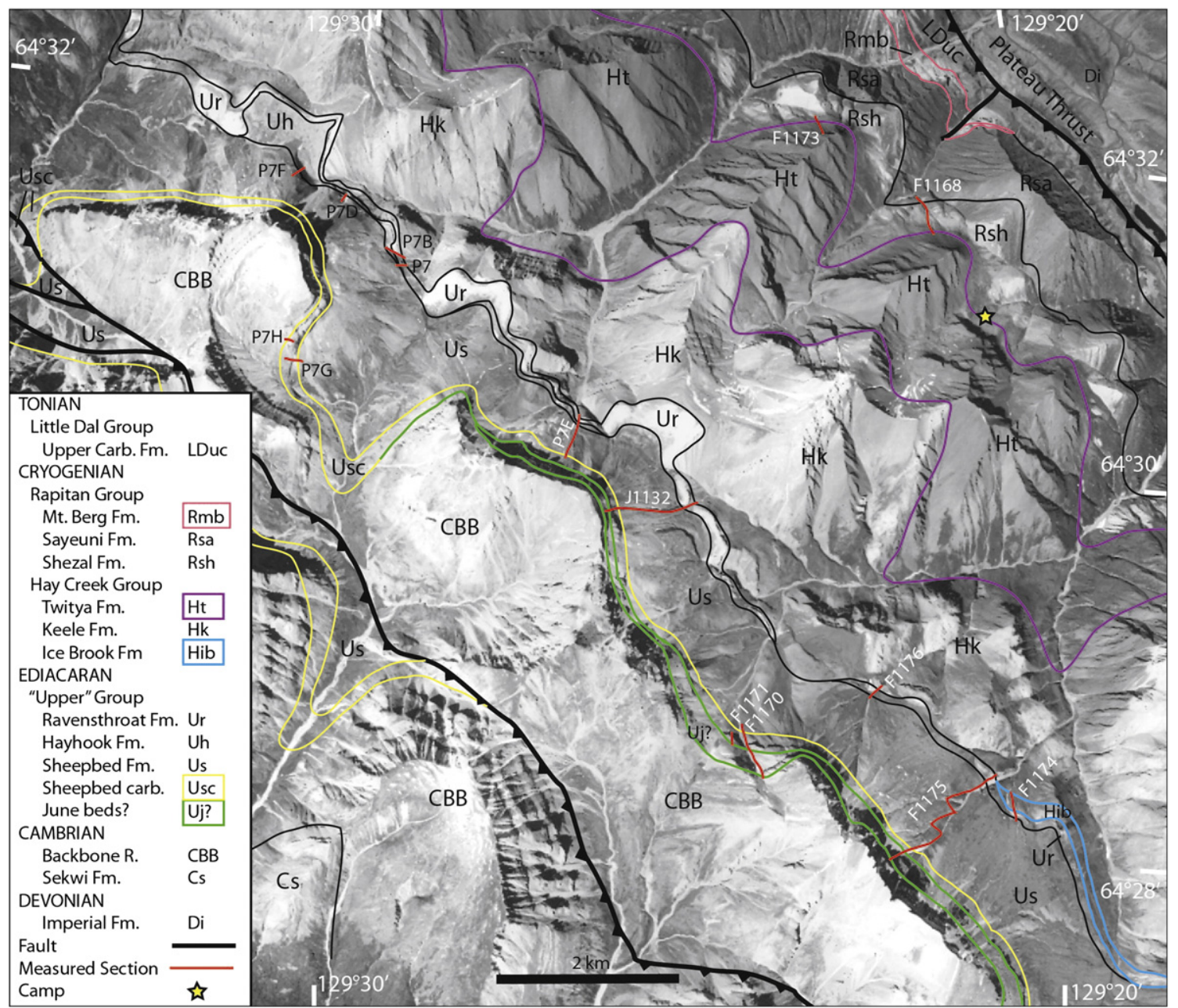

Fig. 2. Annotated airphoto line A24950-108 (Frame 256) of the Shale Lake panel in the central Mackenzie Mountains. The red lines denote the measured sections that are discussed in the text and shown in Fig. 3.

The geology is adapted from Martel et al. (2011) and re-mapped by authors. Shen et al.'s (2008) iron speciation data is from section P7E.

slope break that developed in response to ca. 780-700 Ma rifting of the Rodinian supercontinent (Eisbacher, 1981; Jefferson and Parrish, 1989; Dalrymple and Narbonne, 1996; MacNaughton et al., 2008). Recognition of major facies changes (Aitken, 1989; Narbonne and Aitken, 1995) and large overlapping unconformities within Ediacaran strata (MacNaughton et al., 2000), indicated a more complex tectonostratigraphic architecture. Furthermore, the identification of ca. $570 \mathrm{Ma}$ late Ediacaran syn-rift volcanics in the southeastern Canadian Cordillera (Colpron et al., 2002) challenged the idea of a simple Ediacaran passive margin that developed in response to Cryogenian rifting. Instead, these studies suggest a more nuanced subsidence history. A better understanding of how platformal Ediacaran sections in the Mackenzie, Wernecke and Ogilvie Mountains correlate to deeper water sections preserved near Sekwi Brook (Aitken, 1989; MacNaughton et al., 2000) and potentially to the Selwyn Basin (Gordey and Anderson, 1993; Cecile, 2000; Colpron, 2012) is needed to better assess basin development in a tectono-stratigraphic framework.

\section{Stratigraphy}

In the Mackenzie Mountains, the Ediacaran Period is represented by the Ravensthroat, Hayhook, Sheepbed, Gametrail, Blueflower, and Risky formations (Table 1), which comprise the uppermost portion of the Hay Creek Group and the informal Upper group of the Windermere
Supergroup (Aitken, 1989; James et al., 2001; MacNaughton et al., 2008; Turner et al., 2011). The Ediacaran Upper group can be divided into four major depositional sequences (Pyle et al., 2004), with additional superimposed local sequences that rest unconformably beneath Cambrian siliciclastic and minor carbonate rocks of the Ingta, Backbone Ranges, and Vampire formations (MacNaughton et al., 2000). Here we build upon the sequence stratigraphic architecture defined by MacNaughton et al. (2000) and Pyle et al. (2004) and extend it regionally to refine correlations between the Mackenzie, Wernecke, and Ogilvie Mountains (Fig. 1). Large-scale sequences are represented with numbers (sequences 1-4) and higher order 'simple' sequences (Mitchum and Van Wagoner, 1991; MacNaughton et al., 2000) with letters (a-c).

\subsection{Shale Lake, Mackenzie Mountains}

\subsubsection{Lithostratigraphy}

In the Mackenzie Mountains, Marinoan-age glacial deposits of the Ice Brook Formation are present southwest of the Plateau Thrust on the outer edge of a breakaway paleo-scarp (Aitken, 1991a, 1991b). Near Stelfox Mountain (Fig. 1), the Ice Brook Formation has been separated into three members: megaclast breccia (Durkhan Member), turbiditic siltstone (Delthore Member) and glaciogenic diamictite (Stelfox Member) (Aitken, 1991a; Hoffman and Halverson, 2011). Near Shale Lake (Fig. 1), a wedge of the Ice Brook Formation rests 

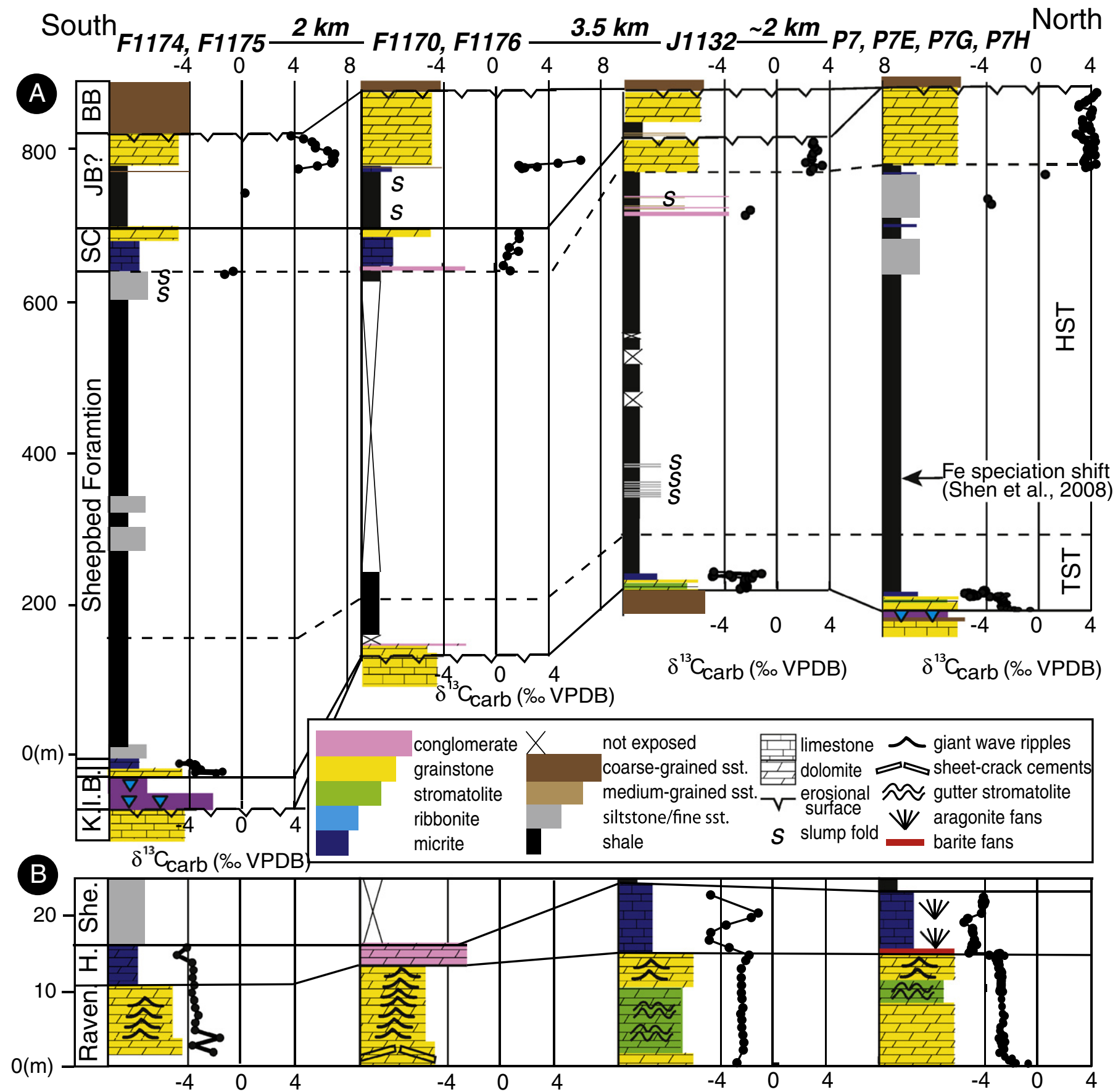

Fig. 3. A) Chemo- and litho-stratigraphic correlation of sections near Shale Lake. TST $=$ transgressive systems tract. HST $=$ highstand systems tract, sst $=$ sandstone, $\mathrm{K}=\mathrm{Keel}$ Formation, I.B. = Ice Brook Formation, SC = Sheepbed carbonate, JB = June beds, BB = Backbone Ranges Formation. B) Same as A, but zoomed in on the transgression preserved in the Ravensthroat (Raven.) cap carbonate. $\mathrm{H}=$ Hayhook Formation, She = Sheepbed Formation.

Carbon isotope data from sections P7G and P7H are from Shen et al. (2008) and data from section P7 are from Hoffman and Halverson (2011).

above the Keele Formation on an erosional unconformity, thickens to the southwest, and consists entirely of the Stelfox Member (Figs. 2 \& 3A). These exposures contain spectacular striated clasts (Fig. 4A) and are sharply overlain by the Ravensthroat formation (James et al., 2001; equivalent to the "Teepee Dolostone" of Aitken, 1991a), which consists of buff colored micropeloidal dolostone that hosts corrugated elongate stromatolites that look like tubestone stromatolites in cross-section (James et al., 2001; Hoffman and Halverson, 2011) and giant wave ripples (Allen and Hoffman, 2005). On the southern end of the Shale Lake panel (Fig. 2), these sedimentary structures are not present, and the basal $3 \mathrm{~m}$ of the Ravensthroat formation contains sheet-crack cements (Hoffman and Macdonald, 2010). Generally, the Ravensthroat formation is up to $15 \mathrm{~m}$ thick and is overlain by $0-10 \mathrm{~m}$ of limestone with aragonite fan pseudomorphs of the Hayhook formation (James et al., 2001). Barite fans and stratiform deposits are also discontinuously preserved along the contact between the Ravensthroat and Hayhook formations (Figs. 2 \& 3, sections P7 \& P7E; Hoffman and Halverson, 2011; Hoffman et al., 2011), but in more distal sections to the south both the pseudomorphosed aragonite fans and the barite deposits are absent (Fig. 4B). 


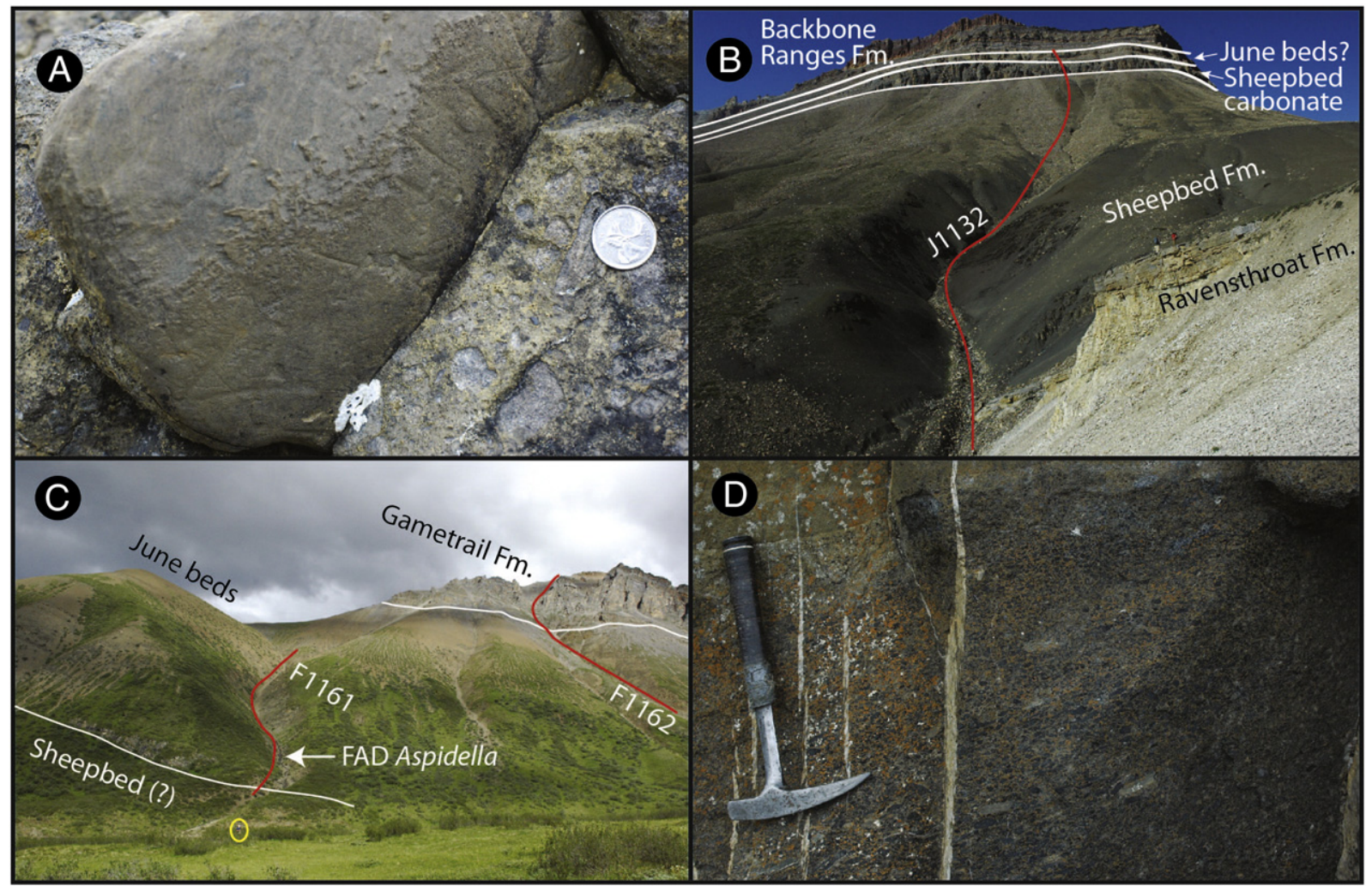

Fig. 4. Field photographs from Shale Lake and Sekwi Brook, Mackenzie Mountains: A) Striated clast in Ice Brook Formation from section F1174 at Shale Lake with the position shown in Fig. 2. Canadian quarter for scale. B) Section J1132 of the Ravensthroat and Sheepbed formations at Shale Lake, looking west. Geologists (for scale) are standing on the top of the Ravensthroat Formation, which in this locality is composed predominantly of gutter stromatolites and giant wave ripples. Section location shown in Fig. 2 and chemo- and litho-stratigraphy shown in Fig. 3. Note the characteristic jet black color of the basal Sheepbed Formation. C) June beds at Sekwi Brook, previously assigned to the Sheepbed Formation, looking northeast at positions of measured sections F1161 and F1162. Note the brown color of the June beds, which is very distinct from the jet black Sheepbed Formation shown in B. Geologist circled for scale. D) Carbonate clast channel fill below the FAD of Aspidella at Sekwi Brook containing coarse quartz sand and giant ooids at the base of the June beds shown in $\mathrm{C}$.

The overlying Sheepbed Formation is predominantly composed of black fissile shale that forms distinct, dark-weathering recessive slopes and saddles. In its type section at Sheepbed Creek in the southern Mackenzie Mountains, the Sheepbed Formation is $>750 \mathrm{~m}$ thick and unconformably overlain by the Backbone Ranges Formation (Gabrielse et al., 1973). At Shale Lake, the Sheepbed Formation is 450-700 m thick and dominated by black shale with minor intervals of normal-graded siltstone (Figs. 3B, 4B). In the uppermost $\sim 100 \mathrm{~m}$ of the Sheepbed Formation, the proportion of siltstone increases, which is locally associated with $0.5-1.1 \mathrm{~m}$ thick intervals of slump folding. Massive and heavily recrystallized light blue to gray colored dolomite with occasional ooids, domal stromatolites, and minor quartz sand are present between the Sheepbed Formation and the sub-Cambrian unconformity (Fig. 4b). This carbonate was originally termed the "Sheepbed carbonate" by Aitken $(1982,1984)$, but was later regarded as the shallow-water equivalent of the Gametrail Formation (Aitken, 1989), a nomenclature that has been subsequently used by many geologists (e.g. Narbonne and Aitken, 1990, 1995; Dalrymple and Narbonne, 1996; Kaufman et al., 1997; MacNaughton et al., 2008; Shen et al., 2008; Hoffman and Halverson, 2011). However, our new correlations with the type section of the Gametrail Formation at Sekwi Brook (discussed below) suggest a different interpretation, namely that these strata are significantly older than the Gametrail Formation (Fig. 5); therefore, we recommend reverting to Aitken's (1982) original informal name of "Sheepbed carbonate" for this unit (Table 1). To the southwest of Shale Lake this massive dolomite unit thins abruptly and an additional sedimentary sequence is present below the sub-Cambrian unconformity (Fig. 4b, c). This additional sequence begins above a prominent karst surface with $\sim 80 \mathrm{~m}$ of thin- to medium-bedded normal-graded sandstone locally interbedded with black shale and channelized conglomerate. These strata are succeeded by a second massive pink colored dolostone unit that is up to $100 \mathrm{~m}$ thick. The normal-graded sandstone beds are interpreted as proximal turbidites and the conglomerate beds are composed of angular carbonate clasts that are interpreted as debris flow deposits. We tentatively correlate this expanded sequence with the informal June beds (discussed below), which are named after exposures in the Sekwi Brook area. However, this sequence could alternatively be correlative with the Blueflower Formation.

\subsubsection{Sequence stratigraphic architecture}

The Ravensthroat formation defines the base of the post-glacial transgressive system tract (TST) of our Sequence 1. The lower $\sim 100 \mathrm{~m}$ of shale are the darkest and most fissile, and contains the maximum flooding surface (MFS) of Sequence 1 . We define the succeeding highstand system tract (HST) where siltstone and slump folding become more prevalent upsection (Fig. 3), as well as the appearance of localized carbonate debris to represent highstand shedding associated with the development of a nearby prograding carbonate platform (Schlager et al., 1994). An alternative interpretation is that an additional small-scale sequence is present at the base of the Sheepbed carbonate and the appearance of pure carbonate marks a TST followed by a HST in the massive facies. It is currently unclear if the overlying sequence assigned tentatively to June beds represents sequence 2, 3 or 4 , because these sequences are irregularly preserved between overlapping unconformities (MacNaughton et al., 2000, 2008). 


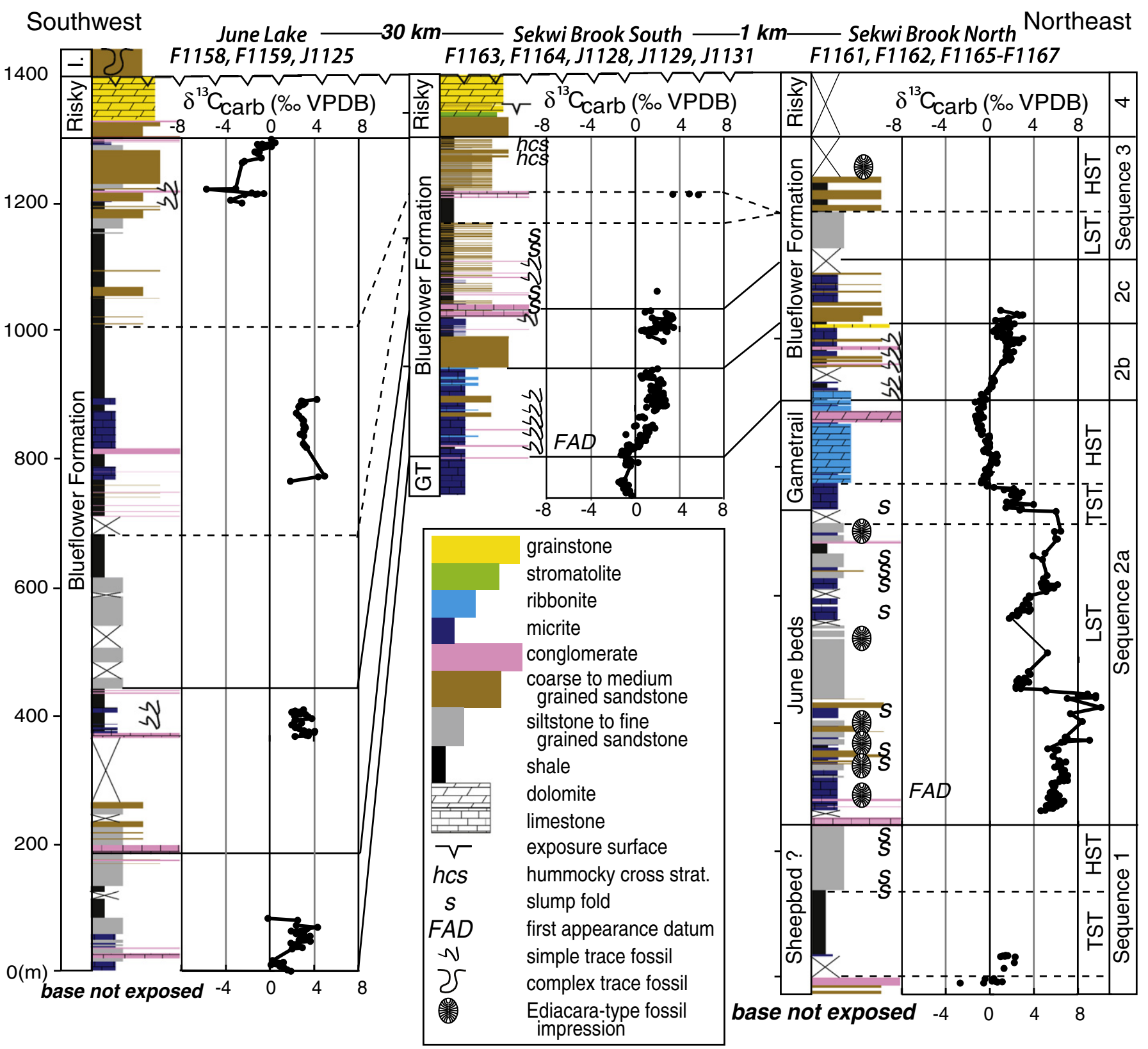

Fig. 5. Chemo- and litho-stratigraphic correlation of sections at Sekwi Brook and near June Lake. TST $=$ transgressive systems tract, HST $=$ highstand systems tract, LST $=$ lowstand systems tract, FSST = falling stage systems tract, I = Ingta Formation, GT = Gametrail Formation. Vertical scale is the same on all stratigraphic columns.

\subsection{Sekwi Brook and June Lake, Mackenzie Mountains}

\subsubsection{Lithostratigraphy}

At Sekwi Brook, all of the fine-grained siliciclastic strata below the Gametrail Formation have been previously correlated with the Sheepbed Formation (e.g. Aitken, 1989; Narbonne and Aitken, 1990, 1995; Dalrymple and Narbonne, 1996; Kaufman et al., 1997; MacNaughton et al., 2008; Shen et al., 2008). However, these deposits are predominantly composed of normal-graded beds of sandstone and lime-rich mudstone, which are lithologically distinct from the fissile black shale that dominates the Sheepbed Formation at the type section (Gabrielse et al., 1973) and in exposures near Shale Lake (Fig. 4b \& c). Importantly, although Dalrymple and Narbonne (1996) suggested the conglomerate at the base of the succession could be correlative with the Marinoan-age Ice Brook Formation, the lowermost exposed strata at Sekwi Brook does not have a base and does not overlie strata characteristic of the Ravensthroat, Ice
Brook, or Keele formations. Consequently, it is ambiguous whether any of these strata are equivalent to the Sheepbed Formation at its type locality or that exposed near Shale Lake.

At Sekwi Brook, Ediacaran exposures begin above a large thrust fault with discontinuously exposed limestone micrite breccia that are overlain with $\sim 200 \mathrm{~m}$ of gray shale and siltstone with occasional slump folding that increases in abundance up-section (Fig. 5). This basal succession is the only portion of this section that is potentially correlative with the Sheepbed Formation at the type locality, and consequently we refer to it as Sheepbed (?); however, we emphasize that this succession could be a separate shale-dominated sequence that is younger than the Sheepbed Formation sensu stricto. These basal strata are unconformably overlain by $\sim 450 \mathrm{~m}$ of thin-bedded carbonate and siliciclastic strata with common normal grading and minor conglomerate that we refer to informally as the "June beds" (Figs. 4c, 5), after nearby June Lake. The basal contact of the June beds is marked by a $>10 \mathrm{~m}$-thick channelized and matrix-supported cobble-clast 

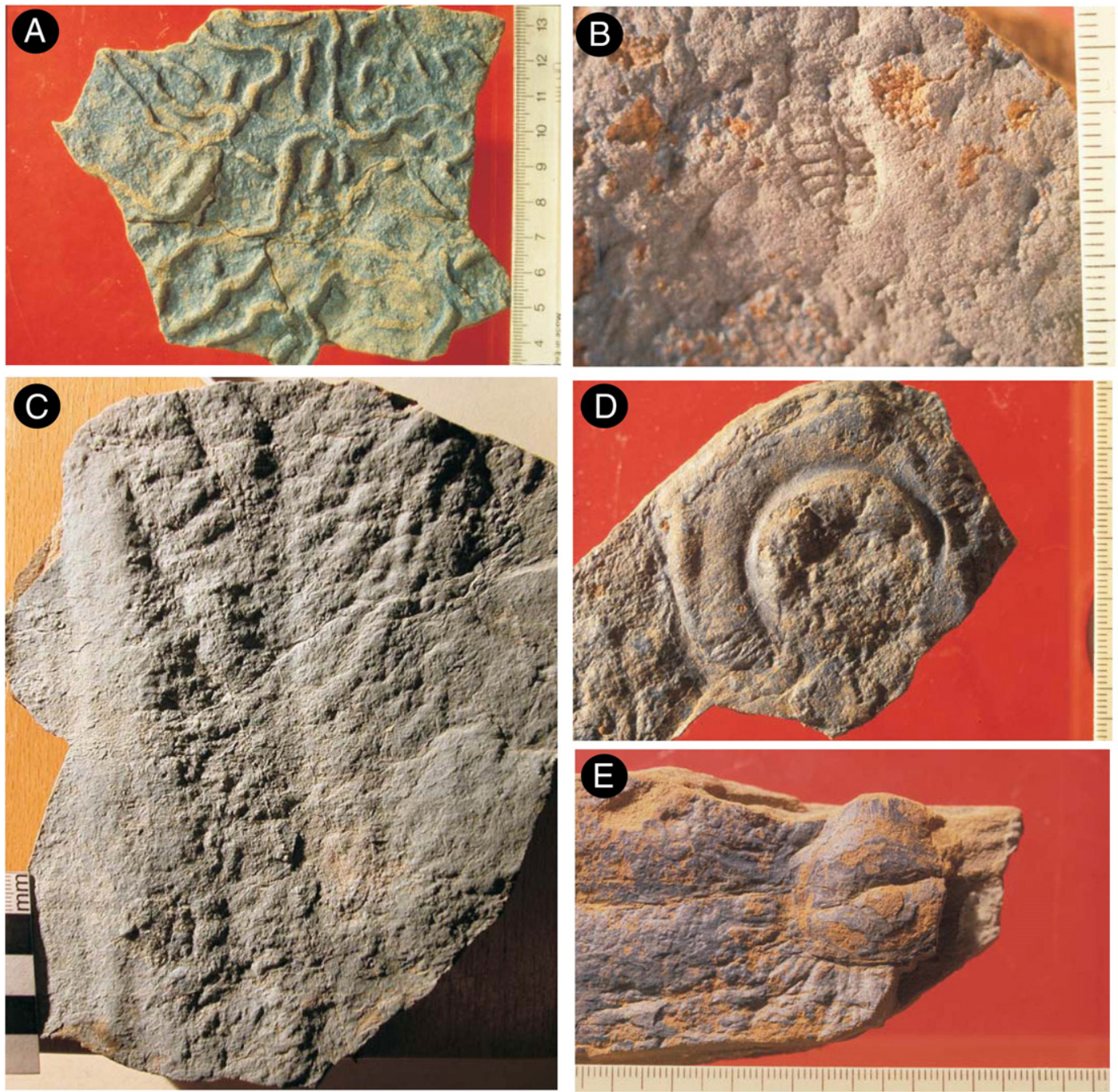

Fig. 6. Ediacaran trace fossils (A) and megafossils (B-E) from the Blueflower Formation (A-B) and the June beds (C-E). All images are from Sekwi Brook. (A) Helminthopsis, a bilaterian burrow. (B) Windermeria, a putative dickinsonid. (C) Beothukis, a rangeomorph frond. (D) Aspidella, a simple discoid holdfast. (E) Hiemalora, a tentaculate holdfast. Scale bars are metric, with divisions in $\mathrm{mm}$ and $\mathrm{cm}$.

conglomerate with giant ooids ( $>2 \mathrm{~mm}$ ) and medium- to coarsegrained quartz sand and detrital mica (Fig. 4d), which we interpret as a debris flow deposit. A section measured $\sim 1 \mathrm{~km}$ to the south demonstrates that along strike the base of this conglomerate cuts down $\sim 100 \mathrm{~m}$ into the underlying shale succession. Above this conglomerate is an $\sim 30 \mathrm{~m}$ interval of thin-bedded lime-rich mudstone with common normal grading and multiple, smaller channelized conglomeratic lenses. Numerous specimens of the Ediacaran attachment disk, Aspidella, and other Ediacara-type fossils (Fig. 6) are preserved in this interval as impressions on the base of Bouma $\mathrm{C}$ beds (Narbonne and Aitken, 1990), with the FAD occurring $\sim 15 \mathrm{~m}$ above the base of the June beds. In the succeeding $\sim 150 \mathrm{~m}$, slump folding and normalgraded beds of sandstone and siltstone become more common. Above a large slump block of carbonate, $\sim 100 \mathrm{~m}$ from the base of the June beds, this general coarsening-up trend ceases and gray to brown colored siltstone predominates. Within these siltstone beds, ripple cross-lamination with flow orientations parallel to the inferred paleostrandline have been interpreted as evidence of contour currents (Dalrymple and Narbonne, 1996). The upper $300 \mathrm{~m}$ of this succession consists of siltstone, shale, and minor micrite with slump folds again becoming more common upsection (Fig. 5), and these strata are overlain by pure carbonate of the Gametrail Formation (Fig. 4c). Together, the strata that we assign to the June beds have been previously interpreted as slope deposits characterized by debris flows and turbidites (Dalrymple and Narbonne, 1996).

The type sections of the Gametrail (F1162; Fig. 4c) and Blueflower (F1163, F1164, and J1128) formations are located at Sekwi Brook (see Aitken, 1989 for logs and position of sections, but note $\sim 0.5 \mathrm{~cm}$ eastward misplacement of airphoto cover in Aitken's Fig. 8), and they were re-measured here to integrate the chemo-, bio-, and sequence-stratigraphy (Fig. 5). The base of the Gametrail Formation is defined by the first massive carbonate deposit above the underlying, poorly exposed, potentially condensed shale of the June beds. Although the contact is not completely exposed, this transition appears sharp at a $>1 \mathrm{~m}$ scale and may represent a sedimentary slide scar. The type Gametrail Formation is $\sim 200$ m thick and consists predominantly of thin-bedded limestone interbedded with massive carbonate debris flows and olistoliths that are commonly dolomitized and host a distinct "zebra" dolomite texture (Vandeginste et al., 2005). This late-stage dolomitization disappears along strike (Fig. 6) and is not an appropriate marker for correlation. At Sekwi Brook, the contact between the Gametrail Formation and the overlying Blueflower Formation is gradational and defined by the first occurrence of siliciclastic detritus (Aitken, 1989). The first appearance datum (FAD) of simple, bed-parallel trace fossils is nearly coincident with the Gametrail-Blueflower contact, which has led to some 
previous confusion as to what formation hosts the oldest burrows in NW Canada (Aitken, 1989; MacNaughton et al., 2000, 2008). Our detailed study of these horizons has revealed that they occur in the lowermost Blueflower Formation as defined by Aitken (1989). The FAD of trace fossils occurs in a small tributary south of the type section, within beds of interbedded shale and micrite, directly above a massive redeposited dolomite bed that marks the top of the Gametrail Formation. In the type section of the Gametrail Formation, textures in this bed are obfuscated by zebra dolomitization (meter $410-418$ in F1162), but again it is overlain by interbedded micrite and shale with the appearance of siliciclastic beds of shale used to mark the base of the Blueflower Formation (Aitken, 1989). Upsection, bioturbation becomes more common and diverse (Fig. 6a) (Narbonne and Aitken, 1990).

The Blueflower Formation is divided into an informal lower carbonate dominated member that is between 250 and $300 \mathrm{~m}$ thick and an upper siliciclastic member that is also between 250 and $300 \mathrm{~m}$ thick, with large lateral facies and thickness changes (MacNaughton et al., 2000). The lower member is dominated by limestone rhythmite and ribbonite and the upper member is characterized by interbedded shale, thin-bedded sandstone and siltstone, and local channelized matrix-supported conglomerate interpreted as debris flows (Fig. 5). These contain blocks that are several meters across consisting of redeposited shallow-water thrombolites, stromatolites, and sandstone. The uppermost strata of the Blueflower Formation shoal gradationally into medium-bedded sandstone with hummocky cross stratification and abruptly into nearshore facies characterized by trough cross-bedded sandstone, stromatolites, oolitic grainstone, and paleokarst surfaces within the Risky Formation (Fig. 5). At Sekwi Brook, the top of the Risky Formation is represented by a karst surface that roughly corresponds to the Ediacaran-Cambrian boundary (Aitken, 1989).

Approximately $30 \mathrm{~km}$ west in the June Lake area (see Aitken, 1989 for location and description of section), the base of the Ediacaran section is not exposed and the Blueflower Formation is greatly expanded (Fig. 5). The section is more shale-dominated than at Sekwi Brook, and while multiple trace fossil horizons are present, no impressions of the Ediacara biota have been identified. At June Lake, the Risky Formation is unconformably overlain by interbedded sandstone and siltstone of the Ingta Formation, which near its top contains complex trace fossils characteristic of the Lower Cambrian, including Treptichnus pedum (MacNaughton and Narbonne, 1999). The early Cambrian small shelly fossil (SSF) Protohertzina (Conway Morris and Fritz, 1980) occurs in strata now regarded as the uppermost Ingta Formation (Conway Morris and Fritz, 1980; Fritz et al. 1983; Narbonne and Aitken, 1995). Thus, it appears that, at least regionally, the Ediacaran-Cambrian boundary is either lost along the karst surface at the top of the Risky Formation or located within the Ingta Formation.

\subsubsection{Sequence stratigraphic architecture}

For the sequences defined below we have modified the three large-scale sequences and seven high-resolution sequences defined by MacNaughton et al. (2000) for the Gametrail, Blueflower, and Risky formations, and add an additional sequence boundary within the June beds. Following previous studies (Southgate, 1989; MacNaughton et al., 2000) we interpret carbonate deposition to represent transgressive systems tracts and highstand systems tracts of relative sea level (Schlager et al., 1994) and the appearance of sedimentary breccia, slumping, and coarse-grained siliciclastic deposition to reflect relative sea-level fall and progradation of continental deposits.

At Sekwi Brook, above the basal conglomerate, the presence of shale and clean limestone is consistent with deposition during a TST (Fig. 5), and the coarsening up and increase in slump folding and channelized breccia bodies may represent the HST or falling stage systems tract (FSST). We define the base of our Sequence 2a at the

\section{$133^{\circ} 10^{\prime} 0^{\prime \prime} \mathrm{W}$ $133^{\circ} 0^{\prime} 0^{\prime \prime W}$}

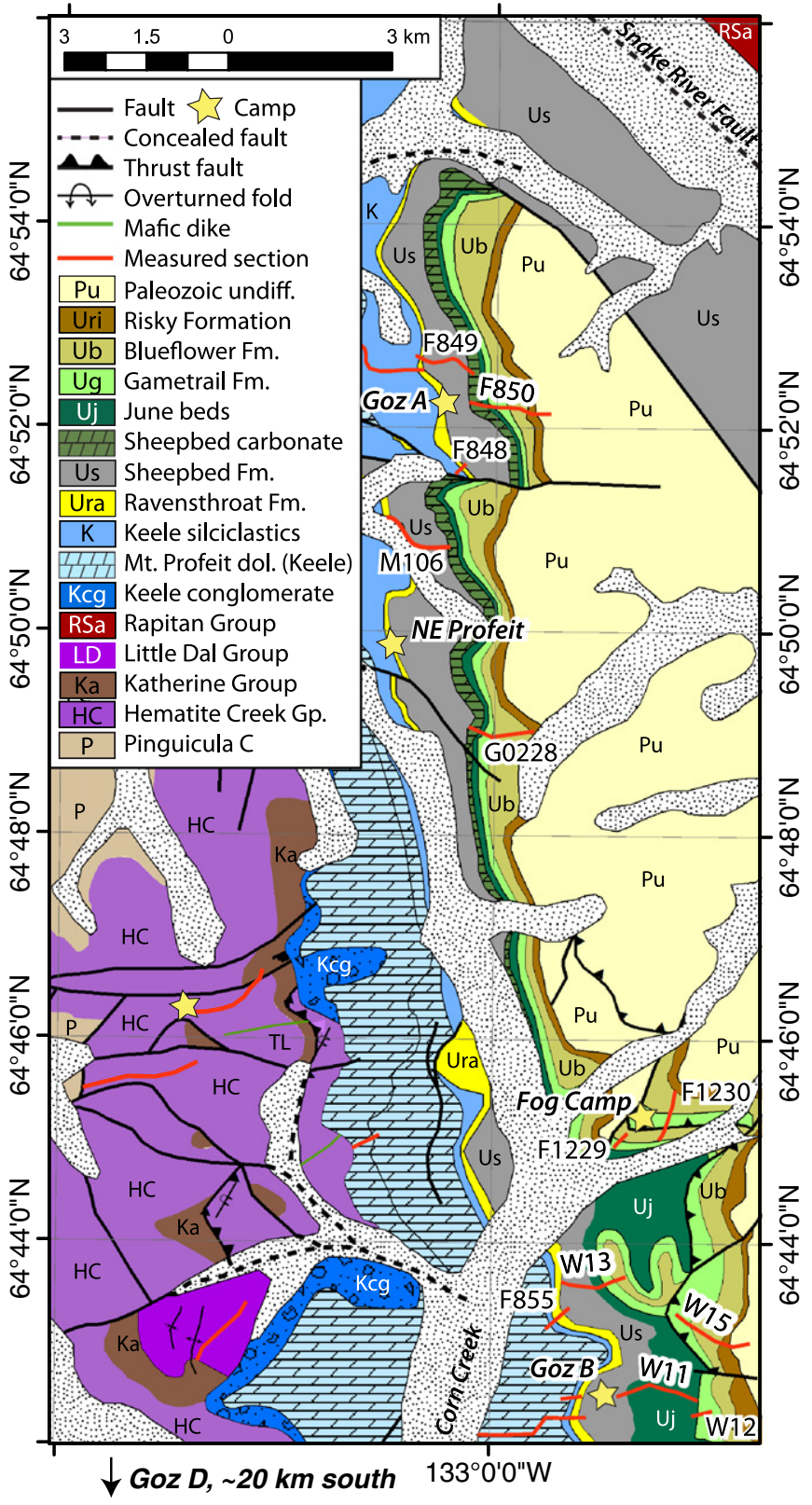

Fig. 7. Geological map of the Goz Creek area, Wernecke Mountains, mapped by authors and adapted from Thorkelson (2000). This map depicts the locations of stratigraphic sections shown in Fig. 8 and discussed in the text. Fm = Formation, dol. = dolostone, Gp. = Group.

thick channelized breccia that unconformably overlies the slumpfolded siltstone and marks the base of the informally defined June beds. The presence of large redeposited ooids, coarse-grained quartz sand, and detrital mica in this deposit, combined with their occurrence directly above slump folded siltstone, argues for their interpretation as LST deposits above a major sequence boundary (Spence and Tucker, 1997). The LST continues upwards with $~ 500 \mathrm{~m}$ of lime-rich mudstone, redeposited carbonate, and thinly bedded sandstone and siltstone with abundant normal grading and slump folding.

The uppermost June beds consist of interbedded shale, limestone, and matrix-supported conglomerate that are interpreted as the TST of Sequence 2a (Fig. 5). These are overlain by limestone of the Gametrail Formation, consistent with a transition from TST to HST deposition (Schlager et al., 1994; MacNaughton et al., 2000). The base of Sequence $2 \mathrm{~b}$ is placed at the appearance of siliciclastic sedimentation at the base of the Blueflower Formation. We interpret the overlying 


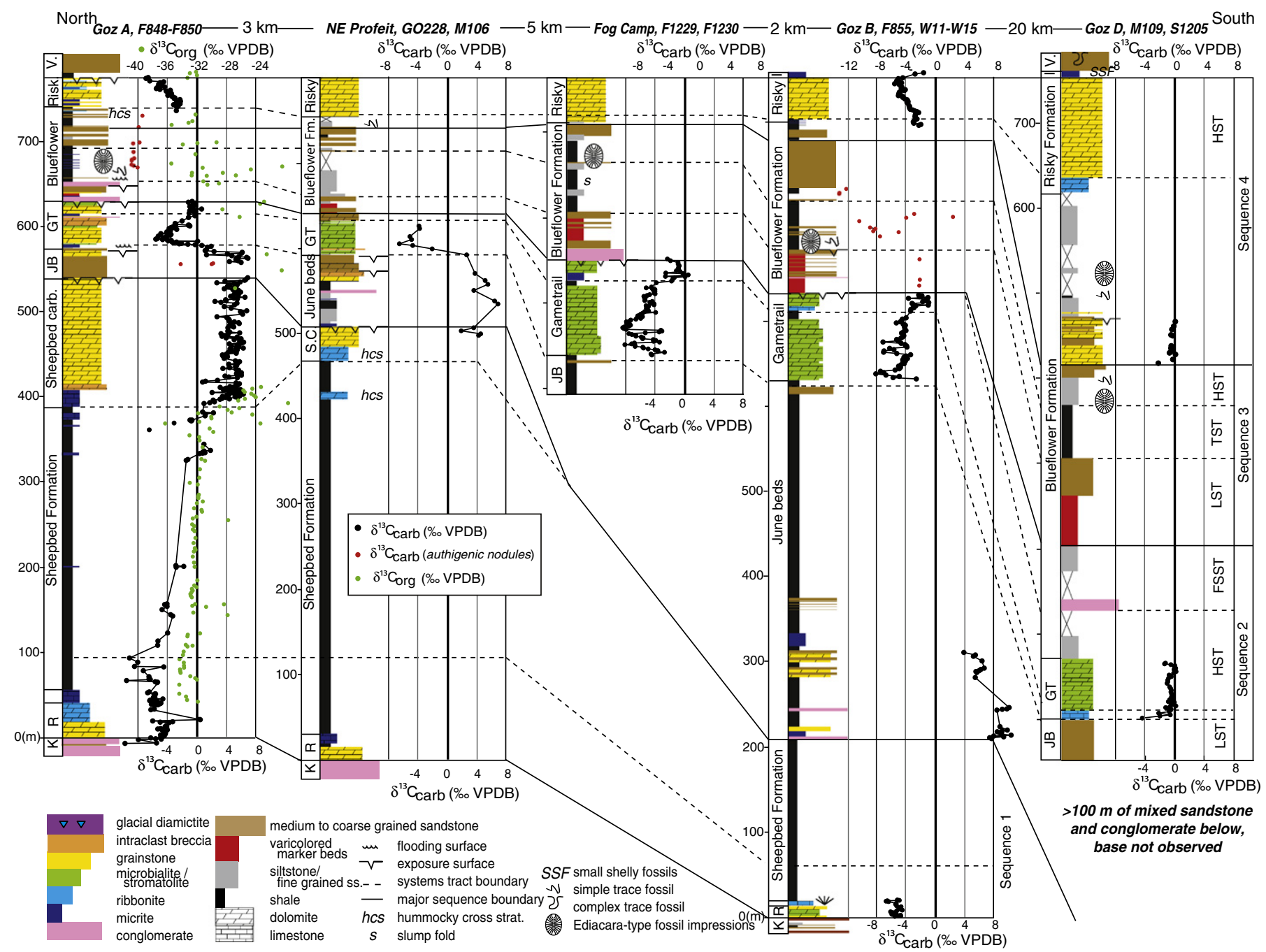

Fig. 8. Chemo- and litho-stratigraphy of the Ediacaran Upper group near Goz Creek, Wernecke Mountains. Location of sections shown on geological map in Fig. 7. The vertical scale is the same on all of the stratigraphic columns. TST $=$ transgressive systems tract, HST $=$ highstand systems tract, LST $=$ lowstand systems tract, FSST $=$ falling stage systems tract, $\mathrm{K}=$ Keele Formation, $\mathrm{R}=$ Ravensthroat Formation, JB = June beds, GT = Gametrail Formation, I = Ingta Formation, $\mathrm{V}=\mathrm{Vampire}$ Formation.

Organic carbon data from Johnston et al. (2013-in this issue) and Blueflower Formation stratigraphy at Goz D adapted from Pyle et al. (2004).

ribbonite to represent the TST of sequence $2 \mathrm{~b}$ with a MFS in that black shale, followed by an HST consisting of mixed micrite, coarse-grained sandstone, and conglomerate. Our Sequence 2c is equivalent to simple sequence 2 of MacNaughton et al. (2000), which is described in detail therein. At Sekwi Brook, the base of sequence 2c is marked by an abrupt package of massive quartz sandstone with a sharp base, potentially marking a wave ravinement surface. In which case, these sands are port of the sequence $2 \mathrm{c}$ TST and the return to carbonate deposition upsection is consistent with another HST (Southgate, 1989; MacNaughton et al., 2000).

Sequence 3 begins with channelized debris flow conglomerate, breccia and olistoliths in the upper Blueflower Formation. The appearance of these debris flows and olistoliths above an interval of abundant slump folding is consistent with a third major sequence boundary overlain with LST deposits of Sequence 3 (Spence and Tucker, 1997; MacNaughton et al., 2000). In the Sekwi Brook area, higher-frequency sequences within Sequence 3 are described in detail in MacNaughton et al. (2000) as simple sequences 3-5.

The base of Sequence 4 is interpreted as a major sequence boundary marked by the basinward shift of shoreface sandstone above the upper foreslope facies of the Blueflower Formation (MacNaughton et al., 2000). The massive shoreface sandstone beds were interpreted by MacNaughton et al. (2000) to represent the LST and the return to carbonate deposition at the base of the Risky Formation marks the base of the TST of Sequence 4. The Risky Formation is capped by a karstic unconformity that locally has tens of meters of relief and is variably filled with quartz sand marking the top of Sequence 4 (Aitken, 1989; MacNaughton et al., 2000). An additional, locallypreserved shoreface sandstone unit cuts down into the Risky Formation carbonate and is interpreted to represent an additional sequence boundary within the basal Risky Formation in some places (Aitken, 1989; MacNaughton et al., 2000).

\subsection{Goz Creek, Wernecke Mountains}

\subsubsection{Lithostratigraphy}

Near Goz Creek (Fig. 7), the Ice Brook Formation is not present, but a buff-colored dolostone abruptly overlies conglomerate of the uppermost Keele Formation. We assign this distinct dolostone to the Ravensthroat formation and the overlying aragonite fan-bearing limestone to the Hayhook formation (Figs. 8, 9a). At sections F848F850 (Fig. 7; near section A of Narbonne and Hofmann, 1987 and Pyle et al., 2004), the Sheepbed Formation is 350 m thick and consists of black shale with thin limestone micrite beds (Fig. 8). Micritic limestone becomes more common upsection and gradationally transitions into shallow-water dolostone characterized by monotonous, 


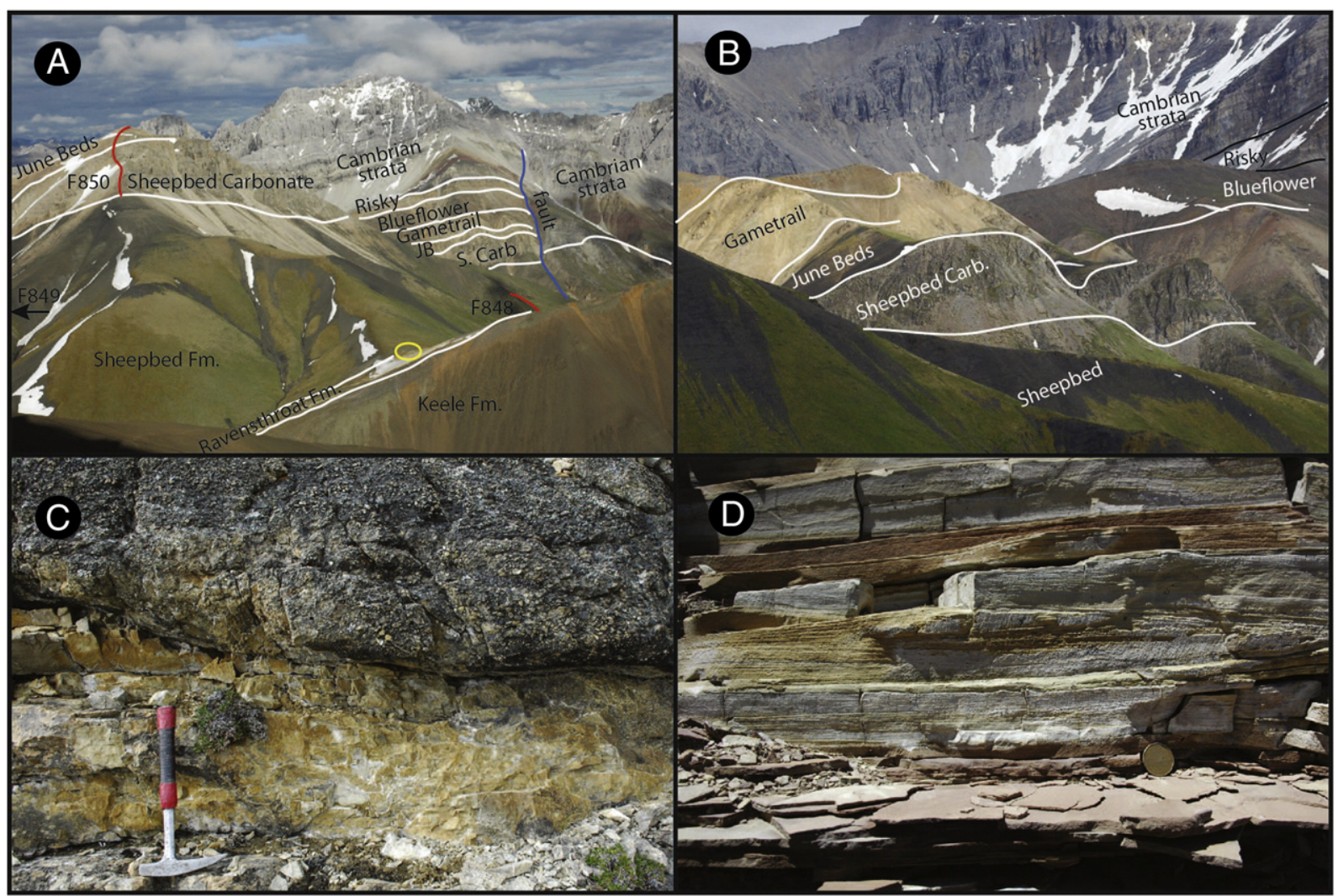

Fig. 9. Field photographs from the Wernecke and Ogilvie Mountains, Northwest Territories and Yukon Territory. A) Ediacaran exposures at section A near Goz Creek with tents circled in yellow for scale; B) Ediacaran exposures at NE Profeit camp showing southward expansion of siliciclastics in the June beds of section GO228; C) Erosional unconformity depicted with conglomerate of the basal Blueflower Formation above microbial dolomite of the uppermost Gametrail Formation at Fog Camp in section F1229; D) Hummocky cross stratification in pink redeposited carbonate of PH4 in section F838 of the Ogilvie Mountains, with location shown in Fig. 10. Canadian dollar coin for scale.

massive dolomite with rare tabular cross-bedding and mm-diameter ooids. This dolostone is capped by a paleokarst surface and unconformably overlain by $\sim 40 \mathrm{~m}$ of coarse-grained sandstone with multiple parasequences capped by exposure surfaces (Pyle et al., 2004). Pyle et al. (2004) correlated this dolostone unit with the Gametrail Formation, but we refer to it here as the Sheepbed carbonate because of its gradational relationship with underlying shale of Sheepbed Formation and its unconformable relation to overlying strata of the newly recognized June beds. We interpret the $\sim 40 \mathrm{~m}$ of siliciclastic strata that overlies the Sheepbed carbonate in this locality as the shallow-water June beds equivalent as they are abruptly overlain by carbonate of the Gametrail Formation (Figs. 8, 9a, b, Table 1). This overlying carbonate succession was previously included with the Blueflower Formation and referred to as the Peritidal member (Pyle et al., 2004), but, given their stratigraphic location above the June beds, we correlate these strata with the Gametrail Formation at Sekwi Brook. At Goz A, the Gametrail Formation consists of $\sim 40 \mathrm{~m}$ of peritidal dolomite stacked in four $\sim 10 \mathrm{~m}$ thick parasequences of rhythmite, ribbonite, stromatolites, and grainstone capped by exposure surfaces of intraclast breccia (Fig. 8). These parasequences culminate in a large unconformity characterized by an incision surface filled with multiple beds of quartz sandstone cobble conglomerate that form the base of the Blueflower Formation (Fig. 8). The basal unit of the Blueflower Formation, referred to as the Yuletide member by Pyle et al. (2004), consists of $\sim 100 \mathrm{~m}$ of interbedded conglomerate, immature sandstone, and varicolored siltstone, which form a marker horizon that can be followed throughout the Goz Creek panel (Fig. 8). The informal Yuletide member is sharply overlain by black shale with interbedded siltstone and sandstone, and lenses and nodules of authigenic carbonate cement. This unit was previously referred to as the 'disk member' (Pyle et al., 2004) in recognition of abundant specimens of the Ediacaran discoid fossils Aspidella, Beltanelliformis (Nemiana), and rare fronds and bilaterian burrows that are preserved on the base of storm-generated event beds (Narbonne and Hofmann, 1987; Narbonne and Aitken, 1990). This assemblage is similar to that of the Blueflower Formation in the Sekwi Brook area, but in the Wernecke Mountains there is evidence for deposition within storm-wave base, including hummocky crossstratification, thereby demonstrating that the Ediacaran biota lived here in a moderately shallow, more agitated environment. The Blueflower Formation shallows upwards into medium to thick beds of coarse-grained sandstone with trough and tabular cross-bedding. These sandstone beds are interbedded with shale for up to $50 \mathrm{~m}$ of stratigraphy. The uppermost Blueflower Formation consists of $\sim 10 \mathrm{~m}$ of interbedded shale and redeposited carbonate, and the base of the Risky Formation is identified by the appearance of pure carbonate. These strata consists of $30-100 \mathrm{~m}$ of pink colored, pure to sandy dolomite, which is capped by a prominent karstic unconformity that hosts local mineralization in the more northerly exposures (Osborne et al., 1986).

Approximately $28 \mathrm{~km}$ to the south of Goz A, at sections W11-W15 (Fig. 7; near section B of Narbonne and Hofmann, 1987 and Pyle et al., 2004), the Sheepbed Formation is less than 200 m thick (Fig. 8) and is directly overlain by the June beds, which expand to the south and consist of $\sim 400 \mathrm{~m}$ of shale with interbedded sandstone and channelized carbonate-clast conglomerate. These conglomerates, which we interpret as debris flow deposits, contain abundant resedimented giant ooids ( $>5 \mathrm{~mm}$ diameter) like those directly below the FAD of Aspidella in the Sekwi Brook area. The June beds differ from the Sheepbed Formation both lithologically, as they are generally coarser-grained and contain more carbonate, and isotopically (see below). At both Goz B and Fog Camp, the Gametrail Formation (Peritidal member of Pyle et al., 2004) 
consists of two microbial dolostone units separated by $\sim 10 \mathrm{~m}$ of shale and limestone ribbonite (Fig. 8).

In the southern-most exposures at Goz D, the Sheepbed Formation and Sheepbed carbonate are not present, and the June beds expand dramatically. There the June beds consist predominantly of thin-bedded siltstone and sandstone, and massive conglomerate interpreted to represent mass-flow deposits. Further south near section Goz D, the lower microbial unit is not present and the Gametrail Formation begins with the limestone ribbonite beds, which rest above sandstone and conglomerate (Fig. 8). There the lower microbial unit of the Gametrail Formation is not present at Goz D, but the upper portion, marked at its base by a distinctive black limestone unit, expands dramatically forming massive reefs. At Goz D the Blueflower and Risky formations also expand, and an additional carbonate unit appears in the upper Blueflower Formation (Fig. 8). In the southernmost sections, Lower Cambrian small shelly fossils Protohertzina and Anabarites and arthropod trace fossils have been described in and above phosphatic carbonates of the overlying Ingta Formation (Nowlan et al., 1985; Pyle et al., 2006).

\subsubsection{Sequence stratigraphic architecture}

We follow the basic large-scale sequence stratigraphic definitions of Ediacaran strata in the Wernecke Mountains of Pyle et al. (2004) with a couple of small exceptions. We place the MFS of Sequence 1 in the lower Sheepbed Formation instead of the upper Sheepbed Formation, and the sequence boundary at the base of Sequence 2a is instead placed stratigraphically lower in the June beds (Fig. 8).

At Goz Creek, the Ravensthroat formation defines the base of the post-glacial TST of Sequence 1. Much like the Shale Lake sections, the lower $\sim 100 \mathrm{~m}$ of shale are the darkest and most fissile, likely approximating the general location of the MFS. In the northern-most

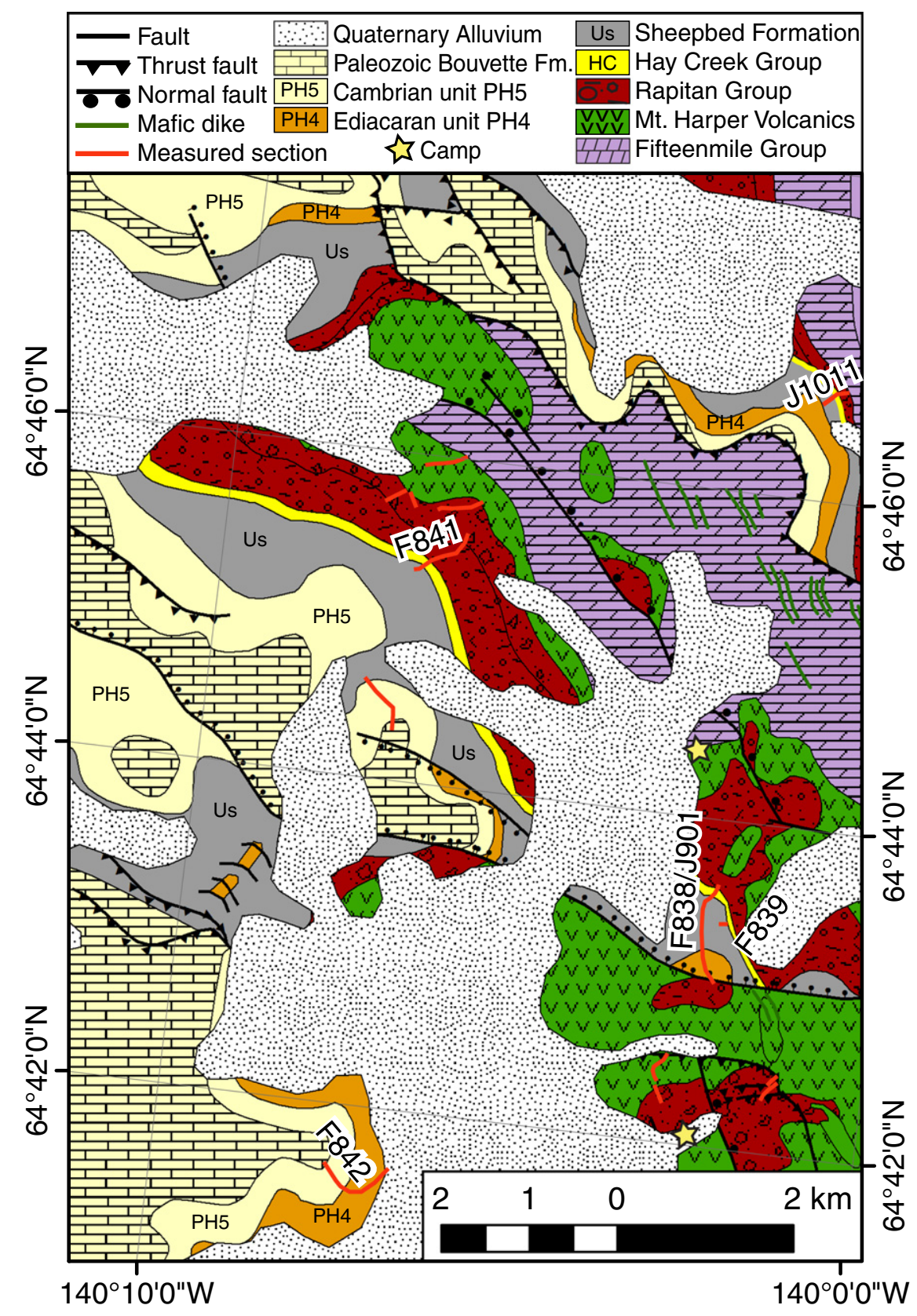

Fig. 10. Geological map of Coal Creek area, Ogilvie Mountains, Yukon, mapped by authors and adapted from Thompson et al. (1994). This map shows the locations of stratigraphic sections depicted in Fig. 11. 


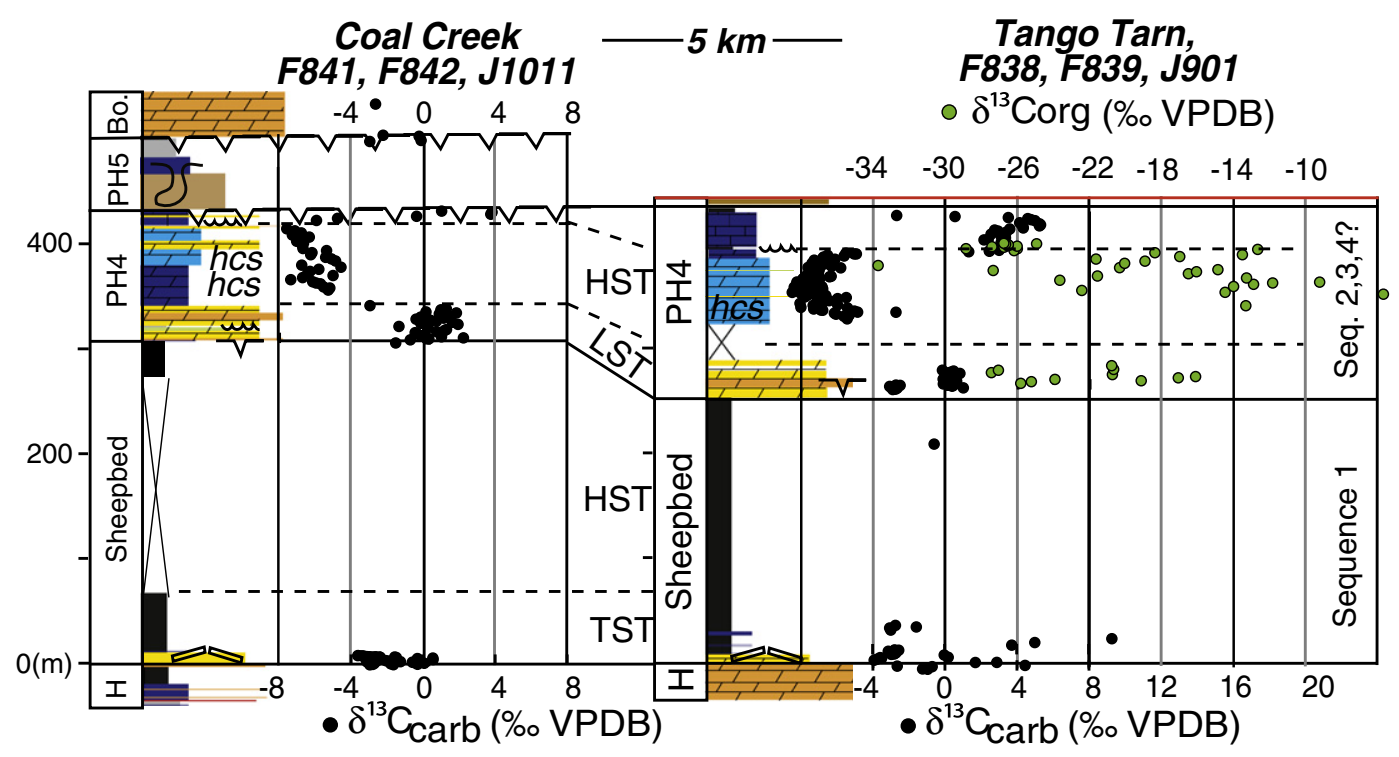

Fig. 11. Chemo- and litho-stratigraphy of stratigraphic sections near Coal Creek, Ogilvie Mountains, Yukon. Positions of measured sections shown in Fig. 10 with legend for symbols in Fig. 8. $\mathrm{H}=$ Hay Creek Group, Bo. = Bouvette Formation, HST = highstand systems tract, LST = lowstand systems tract, TST $=$ transgressive systems tract. Organic carbon data from Johnston et al. (2013-in this issue).

sections near Goz Creek, the appearance of carbonate represents progradation of the margin as the overlying HST continues upwards in a thick carbonate succession of the Sheepbed carbonate. A major karstic unconformity caps Sequence 1 in the more northerly sections (Pyle et al., 2004), which is abruptly overlain by the June beds LST deposits of Sequence 2a. In deeper water sections to the south, the LST of Sequence 2a is represented by the appearance of coarse-grained sandstone and carbonate clast debris flow conglomerate and breccia of the basal June beds (Fig. 8). In our correlation scheme, the LST of Sequence 2a thickens dramatically to the south with the base of section Goz D consisting of $>100 \mathrm{~m}$ of siliciclastic rocks in a lowstand wedge (Fig. 8). In the northernmost sections (Goz A and B), the TST of Sequence 2a is composed of microbial carbonate of the Gametrail Formation (Peritidal carbonate member of Pyle et al., 2004). The thin shale unit with interbedded limestone ribbonite marks the MFS of this TST, and it is succeeded by an additional peritidal carbonate unit that formed during the HST. To the south, this TST is composed of shale and carbonate is only present in the HST.

A major sequence boundary is present at the base of the Blueflower Formation (Yuletide and Disk members of Pyle et al., 2004) with coarse-grained sandstone and channelized conglomerate unconformably overlying the Gametrail Formation. The LST of Sequence 3 consists of varicolored sandstone and siltstone, which are succeeded by black shale and thin sandstone, interpreted to represent the TST and HST of Sequence 3. These outer shelf to upper slope shale and stormgenerated sandstone deposits of Sequence 3 are sharply overlain by thick, amalgamated shoreface sandstone marking the TST of Sequence 4. In the northern-most sections, the base of the Risky Formation approximately marks the MFS, and the overlying carbonate facies generally record a shallowing upward succession into occasionally cross-bedded grainstone. Sequence 4 stratigraphy of the Risky Formation is capped by the prominent karstic sub-Cambrian unconformity.

\subsection{Coal Creek, Ogilvie Mountains}

In the Coal Creek inlier of the Ogilvie Mountains, the predominantly glaciogenic Rapitan Group is succeeded by $<100$ m of poorly exposed siltstone and limestone (formerly map unit PH2; Thompson et al., 1994) that are assigned to the Hay Creek Group (Figs. 10, 11;
Macdonald et al., 2011). The Hay Creek Group commences with $\sim 50 \mathrm{~m}$ of coarse siliciclastic rocks and black shale succeed by $<10 \mathrm{~m}$ of dolomite breccia, which is sharply overlain by a white- to buff-colored, finely laminated dolostone with abundant bed-parallel (sheet-crack) cements that shares textural and geochemical similarities with the Ravensthroat formation (James et al., 2001) and basal Ediacaran cap carbonates worldwide (Hoffman et al., 2007; Hoffman and Macdonald, 2010). Consequently, we assign this unit to the Ravensthroat formation of the Hay Creek Group. These strata are overlain by the informal Upper group (map units PH3-PH5; Thompson et al., 1994), which are well exposed along a ridge and saddle due north of Tango Tarn (Fig. 11; section F838). This exposure begins with $\sim 250 \mathrm{~m}$ of black shale (map unit PH3) that directly overlies the finely laminated dolomite beds discussed above and are tentatively correlated with the Sheepbed Formation. The black shale is succeeded by carbonate strata of map unit PH4 (Thompson et al., 1994; Mustard and Roots, 1997; Macdonald et al., 2010), which consists of a lower dolomitedominated unit and an upper interbedded black shale and limestone unit. The $\sim 25 \mathrm{~m}$ thick dolomite is characterized by massive white to buff-colored recrystallized dolostone with pervasive brecciation and secondary cements, which are overlain by an additional $\sim 100 \mathrm{~m}$ of thinly bedded, pink dolo-rhythmite and ribbonite with hummocky cross-stratification, fine-grained dolomitic sandstone, and occasional stromatolites (Fig. 9b, c). These strata are succeeded by recessive shale and $\sim 10 \mathrm{~m}$ of dark-colored organic-rich limestone. It is unclear if map unit PH4 is correlative with the Gametrail or Risky formations, and as such, we retain the map unit name until future work addresses this. These carbonate beds are overlain unconformably by as much as $170 \mathrm{~m}$ of fine-grained siltstone and sandstone (PH5) that host complex trace fossils, such as Cruziana and Rusophycus (Mustard et al., 1988). A similar succession, albeit poorly exposed, occurs to the west along the Alaska-Yukon border in the Tatonduk Inlier (Macdonald and Cohen, 2011; Macdonald et al., 2011).

\subsubsection{Sequence stratigraphic architecture}

In the Coal Creek inlier, unit PH3 (Sheepbed Formation) rests above the Ravensthroat cap dolomite and represents the TST and HST of Sequence 1 . The base of the overlying unit PH4 is not exposed, but is inferred to be abrupt as no evidence for any transitional facies have 
been observed between the massive dolomite and the underlying Sheepbed Formation. We interpret this to represent an unconformity that removed at least the Sheepbed carbonate and June beds. Although the beds above the basal dolostone breccia of map unit PH4 are thinly bedded, they contain more siliciclastic material and coarsen upwards, and as such broadly define at HST. Because these strata are unconformably bounded by both Sequence 1 and overlying Cambrian strata of map unit PH5, this sequence could be assigned to either Sequence 2, 3 or 4 .

\section{Geochemistry}

\subsection{Carbon and oxygen isotope chemostratigraphy}

\subsubsection{Methods}

We report 1724 new carbonate carbon and oxygen isotope measurements (data tables are available in the Data repository). Samples were cut perpendicular to lamination, revealing internal textures, and between 5 and $20 \mathrm{mg}$ of powder were micro-drilled from the individual laminations (where visible), avoiding veining, fractures, and siliciclastic components. Subsequent $\delta^{13} \mathrm{C}_{\text {carb }}$ and $\delta^{18} \mathrm{O}_{\text {carb }}$ analyses were performed on aliquots of this powder acquired simultaneously on a VG Optima dual inlet mass spectrometer attached to a VG Isocarb preparation device (Micromass, Milford, MA) in the Harvard University Laboratory for Geochemical Oceanography and on a Nu Perspective dual inlet mass spectrometer attached to a Nu carb preparation device (Nu Instruments, Wexham, UK) at McGill University. Micro-drilled samples were reacted in a common, purified $\mathrm{H}_{3} \mathrm{PO}_{4}$ bath at $90{ }^{\circ} \mathrm{C}$ where evolved $\mathrm{CO}_{2}$ was collected cryogenically and analyzed using an in-house reference gas. External error $(1 \sigma)$ from standards was better than $\pm 0.1 \%$ for both $\delta^{13} \mathrm{C}$ and $\delta^{18} \mathrm{O}$. Samples were calibrated to VPDB (Value of the Pee-Dee Belemnite) using the Cararra marble standard. Increased reaction times $(\sim 7 \mathrm{~min})$ were used to minimize any potential memory effect resulting from the common acid-bath system. Carbon $\left(\delta^{13} \mathrm{C}\right)$ and oxygen $\left(\delta^{18} \mathrm{O}\right)$ isotopic results are reported in per mil notation of ${ }^{13} \mathrm{C} /{ }^{12} \mathrm{C}$ and ${ }^{18} \mathrm{O} /{ }^{16} \mathrm{O}$, respectively, relative to the standard VPDB. Organic carbon data is reported in Johnston et al. (2013-in this issue).

\subsubsection{Results}

At all localities described in this study, the Ravensthroat formation is characterized by a sigmoidal $\delta^{13} \mathrm{C}_{\text {carb }}$ signal with values ranging from -2 to $-6 \%$ o (Figs. 3, 8, 11). These results are consistent with previous studies (James et al., 2001; Hoffman and Halverson, 2011). Above the Ravensthroat formation, $\delta^{13} C_{\text {carb }}$ values in the Sheepbed Formation rise steadily upsection reaching positive values just below the base of the Sheepbed carbonate. At Goz A, organic carbon isotope values do not covary with carbonate carbon in the Ravensthroat formation, but tightly covary throughout the $\delta^{13} \mathrm{C}_{\text {carb }}$ rise in the Sheepbed Formation, consistently offset from carbonate by roughly $30 \%$. Total organic carbon content (TOC) is modest at the base of the Sheepbed Formation $(0.1 \mathrm{wt} . \%)$ with a pronounced enrichment of $>0.4 \mathrm{wt}$.\% between 100 and $225 \mathrm{~m}$. In the uppermost siliciclastic component of the Sheepbed Formation, values approach 0.2 wt.\%. Carbon and oxygen isotopes show weak covariance in the Ravensthroat and Sheepbed formations (see Data repository).

Carbonate carbon isotopes in the Sheepbed carbonate are generally enriched, ranging between +4 and $+6 \%$. Although carbonate content is high in these sections, these dolomites were too lean in TOC for $\delta^{13} C_{\text {org }}$ analyses. Carbonate carbon isotope values are even more enriched in the overlying June beds reaching values of $+10 \%$ 。 in some sections (Fig. 5). These extremely enriched values are useful for correlation purposes and aid in distinguishing carbonate debris flows deposits in the June beds from those of the Sheepbed Formation.

In the Goz Creek area, the isotopic composition of the Gametrail Formation preserves a dramatic negative carbon isotope anomaly of $>10 \%$, from $+6 \%$ in the upper June beds to a nadir of $\sim-8 \%$, and then recovers to near $0 \%$ before the Gametrail-Blueflower contact (Fig. 8). In both the Goz Creek and Sekwi Brook regions, carbonate content in the Gametrail excursion is generally greater than $90 \%$. Carbon and oxygen isotopes weakly covary in the Goz Creek area $\left(R^{2}=0.2\right.$ in F850), and do not covary at Sekwi Brook. The Gametrail excursion is poorly developed in the Sekwi Brook sections, where the nadir only reaches $-1 \%$. Although the Gametrail Formation consists largely of zebra dolomite in its type locality, testifying to significant late-stage fluid flow (Aitken, 1989; Vandeginste et al., 2005), along strike the zebra dolomite can be avoided and the Gametrail Formation consists of micritic limestone rhythmites. Carbonate carbon isotope trends in the limestone-dominated and the dolomitized sections are indistinguishable from one another (Fig. 5), but oxygen isotope values are variable (see Data repository), suggesting that the carbonate carbon was buffered with respect to the dolomitizing fluids, but the oxygen was not (Banner and Hanson, 1990). Thus, it appears that the dolomitization is not responsible for the less depleted carbon isotope trends of the Gametrail Formation in the Sekwi Brook area.

Sparse $\delta^{13} \mathrm{C}_{\text {carb }}$ data from nodular carbonates and carbonate cemented shale and siltstone of the Blueflower Formation at Goz Creek record scattered $\delta^{13} C_{\text {carb }}$ values down to $-13 \%$ (Fig. 8; see Data repository). These samples have low carbonate contents, averaging $\sim 63 \%$ for samples with $\delta^{13} \mathrm{C}_{\text {carb }}$ below $-7 \%$ TOC is modest (0.1 wt.\%), with 2 anomalous sample enrichments of $>0.4 \mathrm{wt} . \%$, and $\delta^{13} \mathrm{C}_{\text {org }}$ does not vary systematically, ranging from as enriched as $-20 \%$ odown to $-35 \%$ 。 (Fig. 8). At Sekwi Brook, carbonate dominated limestone rhythmite and ribbonite samples have $\delta^{13} \mathrm{C}_{\text {carb }}$ values that average $+2 \%$. Thus, the scattered, extremely negative values from the Blueflower Formation at Goz Creek are likely the product of local carbonate authigenesis (e.g. Reimers et al., 1996) and do not represent seawater DIC.

Another large negative carbon isotope anomaly (down to -6\%) is present in the Risky Formation at the Goz A and B sections in the Wernecke Mountains (Fig. 8). Although carbonate content is high in these sections, these dolomites were too lean in TOC for $\delta^{13} \mathrm{C}_{\text {org }}$ analyses. In the two sections sampled near Goz Creek, one section shows weak covariance between carbon and oxygen isotopes $\left(R^{2}=0.3\right.$ in W15; see Data repository), whereas in the other section they are anti-correlative (F850; Fig. 8).

In unit PH4 of the Coal Creek inlier of the Ogilvie Mountains, carbon isotope values begin near $0 \%$ o before plummeting to $-8 \%$ o for $\sim 55 \mathrm{~m}$ of strata (Fig. 11). The $\delta^{13} \mathrm{C}_{\text {org }}$ composition of unit $\mathrm{PH} 4$ at both localities is highly variable, with most samples falling between $-30 \%$ and $-15 \%$ 。 (Fig. 11). The isotopic offset between carbonates and organic matter (often termed $\varepsilon$ ) averages $11 \%$ o $(n=24$, with a standard deviation of $6.5 \%$ ). In the lower dolostones, where the negative $\delta^{13} \mathrm{C}_{\text {carb }}$ anomaly is developed, TOC values average $0.1 \mathrm{wt} . \%$, and range widely with no systematic relationship between epsilon and TOC content (Johnston et al., 2013-in this issue). In these strata, carbonate content averages $75 \%$ ( $n=20$, with standard deviation of $10 \%$ ), and carbon and oxygen isotopes strongly covary ( $\mathrm{R}^{2}=0.7$ in F838; see Data repository). Carbonate content is much higher in dark colored limestone unit in the uppermost PH4 (ave. $=91 \%$ ), and $\delta^{13} \mathrm{C}_{\text {carb }}$ is much more enriched, averaging $+2.5 \%$ (Fig. 11). In these samples TOC is also modest ( $0.1 \mathrm{wt} . \%)$, however, the isotopic offset between $\delta^{13} \mathrm{C}_{\text {carb }}$ and $\delta^{13} \mathrm{C}_{\text {org }}$ is steady and averages $29 \%(\mathrm{~N}=6)$.

\section{Discussion}

\subsection{Regional correlations}

The recognition of four large-scale depositional sequences in both the Wernecke Mountains (Goz Creek) and the central Mackenzie Mountains (Sekwi Brook) provides the starting point for regional correlations, which can then be further refined with bio- and chemostratigraphy. Exposures in the Wernecke Mountains clearly 
demonstrate that the Sheepbed carbonate is the HST deposit of Sequence 1, as opposed to the Gametrail Formation, which was deposited in the TST-HST of Sequence 2. This distinction is further substantiated by the identification of the intervening June beds in both regions and their distinct carbon isotope compositions, with the Gametrail Formation typically yielding isotopically depleted $\delta^{13} \mathrm{C}_{\mathrm{carb}}$ values and the Sheepbed carbonate and June beds recording heavily enriched $\delta^{13} \mathrm{C}_{\text {carb }}$ values (Fig. 12). A direct chemostratigraphic correlation of the Gametrail Formation between different regions is complicated by what appears to be an isotopic gradient. For instance, at Goz B the nadir of the Gametrail negative carbon isotope anomaly reaches $-8 \%$ o whereas at Sekwi Brook no values were observed below $-2 \%$. We attribute the localized poor development of this negative anomaly to condensation associated with the TST-HST in the more distal Sekwi Brook and Goz D sections, which can be seen graphically in the proximal-to-distal transect recorded in the Wernecke Mountains where the anomaly is progressively truncated in deeper sections (Fig. 8). Thus, the lateral variability in this excursion may be due largely to differences in sedimentation rate, which can be supported by our sequence stratigraphic analysis. These new correlations also demonstrate that the FAD of Ediacara-type fossil impressions in northwestern Canada are from the June beds of Sequence 2, not in the early Ediacaran Sheepbed Formation of Sequence 1 from which they were previously reported (e.g. Narbonne and Aitken, 1995; Shen et al., 2008)

Sequence stratigraphic correlations to the Shale Lake region of the Mackenzie Mountains and to the Ogilvie Mountains are confounded by the fact that two of the major sequences seem to be missing at these localities (Fig. 12). At Shale Lake, the Sheepbed Formation rests conformably on the Ravensthroat cap carbonate and is succeeded by an isotopically enriched carbonate that formed in the HST of Sequence 1 (Fig. 3), both features being characteristic of the Sheepbed carbonate preserved at Goz A. Therefore, the Fe-speciation data from Shale Lake that was described by Shen et al. (2008) is from the Sheepbed Formation of Sequence 1, which is not correlative with the FAD of Ediacara-type fossils in the lower LST of Sequence 2 at Sekwi Brook. An additional sequence is present below the sub-Cambrian unconformity at Shale Lake (Fig. 4b) that we tentatively correlate with the June beds (?) because of its enriched carbon isotopic composition (Fig. 3). These strata also fit descriptions of the lower and middle members of the type section of the Backbone Ranges Formation, which MacNaughton et al. (2008) suggested is correlative with the Blueflower and Risky Formations, respectively. Although the carbon isotopic values are much more enriched $(>+6 \%$ ) than the Risky Formation, there could be an additional sequence in the Blueflower Formation that has not been identified and is more isotopically enriched. Further studies of

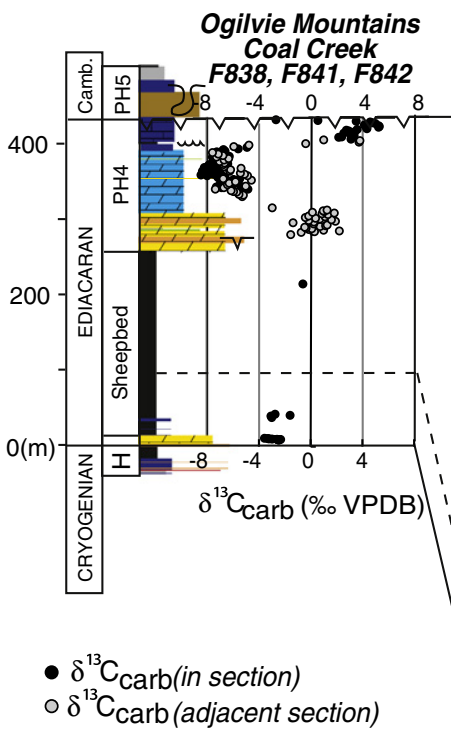

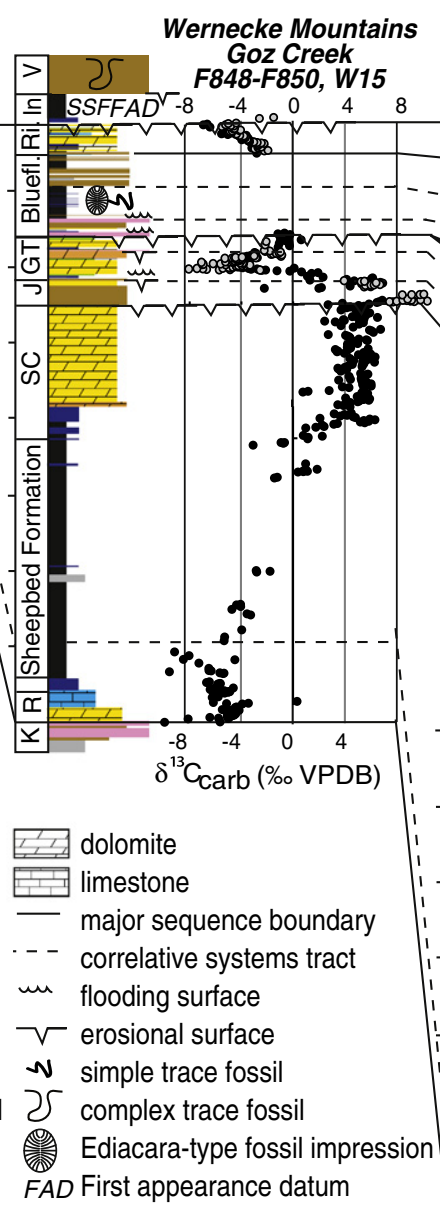
FAD First appearance datum

\section{Central Mackenzie Mountains} Shale Lake
F1174, F1175, J1132, P7 F1174, F1175, J1132,

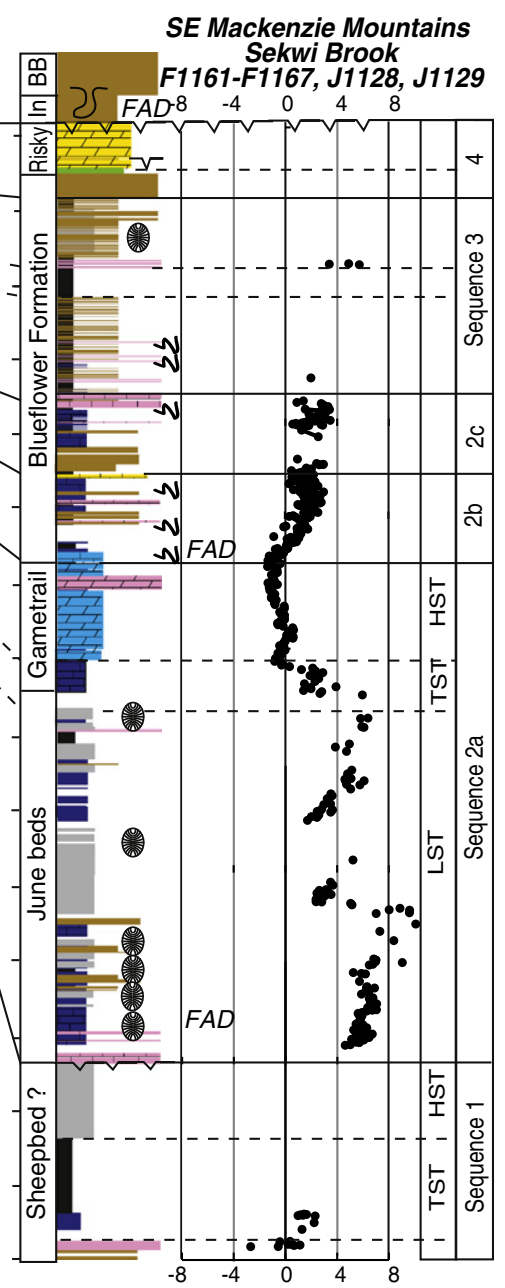

Fig. 12. Composite chemostratigraphy and regional correlations of the Ediacaran Upper group in northwestern Canada. Note that in these composite figures we exclude data from diagenetic carbonate nodules in siliciclastic-dominated intervals and provide some hypothesized ages for the greater stratigraphy based on the age model described in the text and depicted in Fig. 13. TST = transgressive systems tract, HST $=$ highstand systems tract, LST $=$ lowstand systems tract, FSST $=$ falling stage systems tract. The other abbreviations are the same as in Fig. 1. 


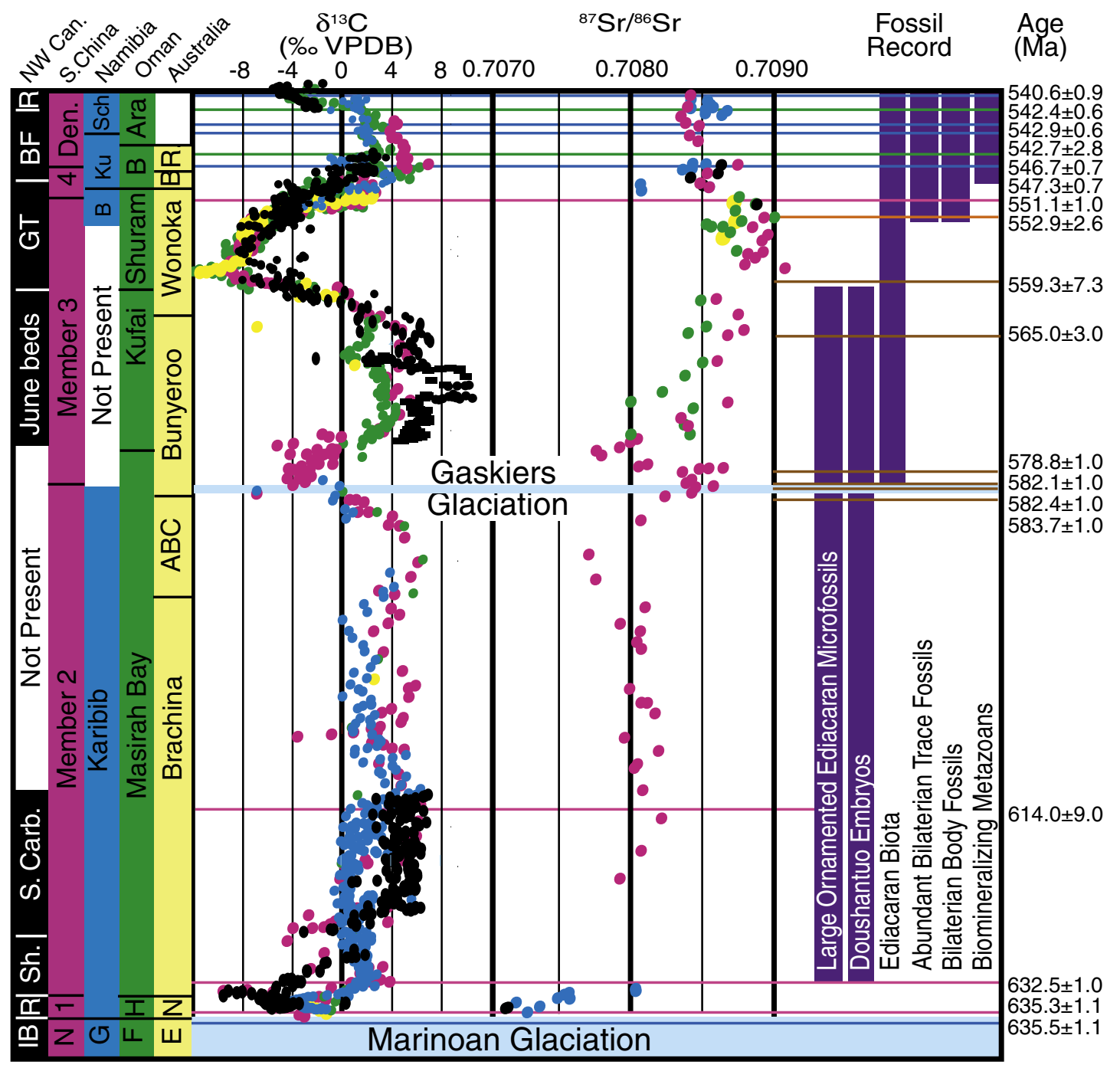

Fig. 13. Global correlations of Ediacaran strata from key locations with associated isotopic, geochronologic, and biostratigraphic data. All of the data is color coded for geographic location: Black = northwestern Canada, Pink = South China, Blue = Namibia, Green = Oman, Yellow = Australia, Orange = White Sea region of Russia, Brown = Avalon Terrane of Newfoundland and the United Kingdom. The approximate depositional span of each formation from which the chemostratigraphic data was utilized is shown on left-hand side, which is purely schematic given the lack of precise age constraints from most of these deposits. Each of these stratigraphic successions contain multiple unconformities of unknown extent, so there are certainly additional intervals in which strata is not present and this is purely meant as an exercise to summarize our current age model for the Ediacaran. The carbon isotope data is from northwestern Canada (this paper), South China (Tahata et al., 2013), Namibia (Halverson et al., 2005), Oman (Fike et al., 2006), and Australia (Calver, 2000). Strontium isotope data is from northwestern Canada (Narbonne et al., 1994), South China (Sawaki et al., 2010), Namibia (Kaufman et al., 1993; Halverson et al., 2007), Oman (Burns and Matter, 1993), and Australia (Foden et al., 2001).

Placement of the Gaskiers Glaciation in the lower Bunyeroo Formation follows Gostin et al. (2010) and the fossil constraints are after Narbonne et al. (2012) and references therein. Geochronological constraints are summarized in Schmitz (2012) with references therein.

the exposures southwest of Shale Lake are needed to resolve these correlations.

In the Ogilvie Mountains, the extremely depleted $\delta^{13} \mathrm{C}_{\text {carb }}$ values recorded in PH4 could suggest correlation to the Gametrail negative excursion; however, the Gametrail excursion reaches its most depleted $\delta^{13} C_{\text {carb }}$ values in a transgressive sequence, returning towards positive values in the HST, whereas the most negative values in PH4 are expressed in an HST. Alternatively, unit PH4 could be correlative with the Risky Formation, which is also characterized by a negative $\delta^{13} \mathrm{C}_{\text {carb }}$ excursion, which is developed in an HST in the Wernecke Mountains (Figs. 8, 12). Moreover, unit PH4 and the Risky Formation both consist of pink colored, sandy carbonate with abundant siliciclastic grains, whereas the Gametrail Formation is composed of relatively pure carbonate.

The appearance of poorly-sorted, immature coarse-grained sandstone and conglomerate units in the June beds, as well as the documentation of rapid facies changes from northeast to southwest in both the central
Mackenzie Mountains and the Wernecke Mountains is suggestive of syn-sedimentary tectonic activity. The broad timing of deposition of the June beds (discussed below; Fig. 13) is consistent with the ca. $570 \mathrm{Ma}$ syn-rift volcanics preserved in the southeastern Canadian Cordillera (Colpron et al., 2002) and with thermal subsidence models, which argue for latest Ediacaran rifting on the western margin of Laurentia (Bond et al., 1983; Bond and Kominz, 1984).

\subsection{Construction of an age model for Ediacaran strata of northwestern Canada}

The Sequence 1 lowstand begins with a Marinoan-age glacial diamictite capped by a basal Ediacaran cap carbonate in the Ravensthroat and Hayhook formations (James et al., 2001; Hoffman and Halverson, 2011), which pins the base of the Ediacaran succession to ca. $635 \mathrm{Ma}$ (Hoffmann et al., 2004; Condon et al., 2005; Knoll et al., 2006). The Sheepbed Formation of Sequence 1 was deposited during the early 
Ediacaran in the post-Marinoan glacio-eustatic transgression and an unknown amount of time is missing at the boundary between Sequences 1 and 2.

In northwestern Canada, a sedimentological record of the Gaskiers glaciation has not been identified; however, globally, the oldest dated Ediacara-type fossils occur directly above the ca. $582 \mathrm{Ma}$ glacial deposits of the Gaskiers Formation within the Avalon assemblage in Newfoundland (Narbonne and Gehling, 2003), which is bracketed by U-Pb zircon ages of $\sim 579$ and $<565 \mathrm{Ma}$ (Bowring et al., 2003; Canfield et al., 2007; Narbonne et al., 2012). The Ediacaran attachment disk Aspidella is common in the June beds at Sekwi Brook (Narbonne and Aitken, 1990; Gehling et al., 2000), first appearing $\sim 15 \mathrm{~m}$ above the channelized debris-flow carbonates that mark its base and extending through the top of the Blueflower Formation. The radiating attachment disk Hiemalora (Narbonne, 1994) and two genera of rangeomorph fronds (Fig. 6) occur sporadically in the middle part of the June beds, and coupled with the apparent absence of extensive bilaterian burrows, this implies a tentative correlation with the Avalon assemblage of Ediacaran megafossils elsewhere dated at 580-560 Ma (Xiao and Laflamme, 2009; Narbonne et al., 2012). Thus, we suggest that the June beds were also deposited between $~ 580$ and $560 \mathrm{Ma}$ and that the Gaskiers glaciation is either represented by, or missing at, the Sequence 1-2 boundary (Fig. 13).

Simple bilaterian burrows first appear and become abundant in the basal beds of the Blueflower Formation (Narbonne and Aitken, 1990; MacNaughton et al., 2000; Pyle et al., 2004). The appearance of these trace fossils, coupled with the single occurrence of the putative dickinsonid Windermeria near the top of the Blueflower Formation, is most consistent with correlation with the ca. $555 \mathrm{Ma}$ White Sea assemblage of Ediacara-type fossils but may also extend into the younger Nama assemblage (Xiao and Laflamme, 2009; Narbonne et al., 2012). However, it should be noted that these Ediacaran assemblages may not represent strict chronostratigraphic tie points as both facies assemblages and depositional environments may also represent a major control on the distribution of Ediacara-type fossils, as is seen in South Australia (Gehling and Droser, 2013).

Upper Ediacaran strata of the Gametrail, Blueflower, and Risky formations each contain negative $\delta^{13} \mathrm{C}_{\text {carb }}$ excursions from enriched baseline values that can potentially be used for global correlation and refinement of the age model for these strata (Fig. 12). However, a closer look at these excursions suggests that they may not share a common origin, which challenges their use as perfect correlative tools. Specifically, the excursions in the Gametrail and Risky formations are in carbonate-dominated strata and are broadly reproducible, whereas the Blueflower anomaly is recorded in nodules and cements preserved within shale dominated strata, which have highly variable $\delta^{13} \mathrm{C}_{\text {carb }}$ values both up-section and along strike. Thus, the negative $\delta^{13} \mathrm{C}_{\text {carb }}$ values in the Blueflower Formation are interpreted as the product of local authigenic carbonate precipitation and are not useful for correlation (e.g. Irwin et al., 1977).

On the other hand, the large carbon isotope anomaly in the Gametrail Formations is potentially correlative with the Shuram carbon isotope excursion. Shuram-like carbon isotope excursions have previously been described in stratigraphic sections from Oman (Burns and Matter, 1993; Fike et al., 2006; Le Guerroue et al., 2006a), Australia (Pell et al., 1993; Calver, 2000; Husson et al., 2012), South China (Condon et al., 2005; Zhou and Xiao, 2007; McFadden et al., 2008), the Tarim block in northern China (Xiao et al., 2004; Shen et al., 2011), India (Kaufman et al., 2006), Siberia (Pokrovskii et al., 2006; Melezhik et al., 2009), Norway (Rice et al., 2011), and Death Valley, California (Corsetti and Kaufman, 2003; Bergmann et al., 2011; Verdel et al., 2011). Extremely negative $\delta^{13} \mathrm{C}_{\text {carb }}$ values preserved in carbonate clasts and in strata immediately below the Mortensnes diamictite in Norway (Rice et al., 2011) suggest that Shuram-like excursions could be as old as the $582 \mathrm{Ma}$ Gaskiers glaciation. An age constraint on the end of Shuram-like anomalies of 551.1 \pm 0.1 Ma comes from unit D of the Doushantuo Formation (Condon et al., 2005), which marks the return to positive $\delta^{13} \mathrm{C}_{\text {carb }}$ values. Similarly, in the Nama Group of Namibia, $\delta^{13} C_{\text {carb }}$ values return from $<-5 \%$ to positive values below an ash bed dated at $548.8 \pm 1 \mathrm{Ma}$ (Grotzinger et al., 1995). A long duration of the Shuram excursion has been supported by thermal subsidence modeling of the Ediacaran succession in Oman, which has been used to argue for a 50 million year duration of negative $\delta^{13} \mathrm{C}_{\text {carb }}$ values associated with the excursion, from ca. 600 to $550 \mathrm{Ma}$ (Le Guerroue et al., 2006b). However, other workers have used U-Pb zircon ages to interpolate a start date of the Shuram excursion in Oman at ca. $560 \mathrm{Ma}$ (Bowring et al., 2007), but there are no direct age constraints within the excursion. Importantly, the presence of two Ediacaran large negative carbon isotope excursions in South China, referred to as the EN2 and EN3 excursions (Zhou and Xiao, 2007; McFadden et al., 2008), opens up the possibility that the true duration of the Shuram excursion has been exaggerated and that the first excursion, EN2, occurred at ca. $580 \mathrm{Ma}$, and that EN3 is correlative with the Shuram excursion and occurred between 560 and $550 \mathrm{Ma}$ (e.g. Narbonne et al., 2012). In this case, the negative carbon isotope values associated with glacial deposits in Norway and on the Tarim block could be correlative with the EN2 excursion instead of the Shuram excursion.

The data presented herein suggest that the Gametrail negative $\delta^{13} \mathrm{C}_{\text {carb }}$ excursion occurred after the first appearance of Ediacaratype fossils in the June beds, but directly before extensive bioturbation in the Blueflower Formation. In Australia, the Wonoka anomaly also occurs well above ice-rafted debris in the Bunyeroo Formation, potentially correlative with the Gaskiers glaciation (Gostin et al., 2010), but below the first appearance of Ediacara-type fossils and bioturbation (Gehling, 2007). Ediacaran fauna have also not been documented below the ca. $582 \mathrm{Ma}$ glacial deposits of the Gaskiers Formation in Newfoundland (Narbonne and Gehling, 2003). Therefore, we suggest that the Gametrail excursion likely postdates both the Gaskiers glaciation and the EN2 excursion, and it is most likely correlative with the Shuram excursion (Fig. 13). A potential weakness in our correlation scheme is that the nadir of the Gametrail excursion only reaches $\sim-8 \%$, but values as low as $\sim-12 \%$ are reported in the Shuram excursions of Oman, Australia, and Death Valley. However, the absolute value of the excursion is not only highly variable both between different local stratigraphic sections in northwestern Canada, but also displays global variability, which may provide revealing features about the nature of the carbon cycle perturbation. An alternative correlation of the Gametrail excursion with EN2 would imply that Ediacara-type fossils in the June beds potentially preceded the Gaskiers glaciation and that pervasive bioturbation occurred much earlier than previously thought (Fig. 13). This does not seem likely given the species-level similarity in taxa from the June beds and the Mistaken Point Formation (Narbonne et al., submitted).

An upper age constraint on the Ediacaran strata of northwestern Canada is potentially provided by the Risky negative carbon isotope excursion, which may be correlative with the ca. 541 Ma PrecambrianCambrian boundary excursion (Bowring et al., 1993; Knoll et al., 1995; Narbonne and Aitken, 1995; Kaufman et al., 1997; Corsetti and Hagadorn, 2000; Amthor et al., 2003; Bowring et al., 2007). Alternatively, the Risky excursion could be the product of meteoric alteration associated with paleokarst development under the sub-Cambrian unconformity (Osborne et al., 1986). Current work is being carried out in attempt to refine the local relationship between the Risky excursion, paleokarst development, and the FADs of complex trace fossils and small shelly fossils in the overlying Ingta Formation.

\subsection{Ediacaran carbon isotope chemostratigraphy}

The Gametrail negative ${ }^{13} C_{\text {carb }}$ excursion shares many characteristics with the Shuram negative carbon isotope excursion preserved around the globe (e.g., Grotzinger et al., 2011). The similarities 
include: 1) $\delta^{13} \mathrm{C}_{\text {carb }}$ and $\delta^{18} \mathrm{O}_{\text {carb }}$ covariation; 2) decreased isotopic offset between $\delta^{13} C_{\text {carb }}$ and $\delta^{13} C_{\text {org }}$; 3 ) development of the negative $\delta^{13} \mathrm{C}_{\text {carb }}$ excursion during a TST and recovery in an HST; and 4) $\delta^{13} C_{\text {carb }}$ values well below mantle $\delta^{13} \mathrm{C}$ input values, but variable between sections. These features present challenges for utilizing the canonical $f_{\text {org }}$ model of carbon isotope composition of seawater (Hayes et al., 1999) to explain this carbon isotope excursion. Particularly, driving the Shuram excursion through simple changes in burial and oxidation of organic matter requires exceptionally large fluctuations in atmospheric $\mathrm{O}_{2}$ (Bristow and Kennedy, 2008). In light of these difficulties, we explore previous models and the implications of a new hypothesis recently proposed by Schrag et al. (2013), which provides an additional mechanism to create changes in $\delta^{13} \mathrm{C}_{\mathrm{carb}}$ through the precipitation and preservation of authigenic carbonate on local and global scales.

\subsubsection{Diagenesis model for the Shuram excursion}

Derry (2010) suggested that the Shuram negative carbon isotope anomaly was a result of deep burial diagenesis by highlighting $\delta^{13} \mathrm{C}_{\text {carb }}$ and $\delta^{18} \mathrm{O}_{\text {carb }}$ covariance in Australia, Oman, South China, and Siberia and performing geochemical modeling to reproduce global negative carbon isotope anomalies with this mechanism. However, isotopic conglomerate tests from the Wonoka Formation of Australia demonstrate that the $\delta^{13} \mathrm{C}_{\mathrm{carb}}-\delta^{18} \mathrm{O}_{\text {carb }}$ covariance was imparted to these rocks prior to their redeposition, and therefore most likely not acquired during deep burial diagenesis (Husson et al., 2012). Importantly, these data do not rule out early authigenesis (Schrag et al., 2013) or meteoric diagenesis (Knauth and Kennedy, 2009; Swart and Kennedy, 2012) as driving mechanisms. In northwestern Canada, Australia, Oman, and South China there are no prominent subaerial exposure surfaces within or directly above the Shuram-like excursions; therefore, meteoric alteration, if it was a driving mechanism for this carbon isotope anomaly, must have occurred in the lower vadose, phreatic, or mixing zone wedges (Melim et al., 2001) associated with different exposure surfaces within the bounding Ediacaran stratigraphy. Because it is unlikely that there was a significant terrestrial biosphere at this time (Sanderson, 2003; Zimmer et al., 2007; Gensel, 2008), extensive organic matter remineralization in the uppermost portion of the sediments near these purported exposure surfaces is implausible, as is the likelihood of global diagenetic events affecting basins with different subsidence histories. Typical meteoric alteration also fails to explain why large-magnitude anomalies appear to be broadly correlative and unique to the Neoproterozoic. Furthermore, $\delta^{13} \mathrm{C}_{\text {carb }}-\delta^{18} \mathrm{O}_{\text {carb }}$ covariance in carbonates is not exclusive to meteoric diagenesis and can be generated other ways, such as through temperature-dependent microbial respiration (Stanley, 2010; Finnegan et al., 2012) or higher bottom water temperatures resulting in higher pore fluid temperatures and lighter $\delta^{18} \mathrm{O}_{\text {carb }}$ in carbonates formed within the sediment (cf., Macdonald et al., 2009). That is, if the $\delta^{13} \mathrm{C}_{\mathrm{carb}}-\delta^{18} \mathrm{O}_{\text {carb }}$ covariance through the Shuram excursion is real and not due to late-stage burial or meteoric diagenesis, there are other potential explanations for these data that involve changes in the temperature and/or the composition of seawater and pore fluids.

\subsubsection{Large DOC model for the Shuram excursion}

Another puzzling feature of Shuram-like excursions in Oman (Fike et al., 2006), South China (McFadden et al., 2008), Australia (Calver, 2000), and now northwestern Canada, is that $\delta^{13} C_{\text {carb }}$ and $\delta^{13} C_{\text {org }}$ do not covary. This lack of $\delta^{13} \mathrm{C}_{\text {carb }}$ and $\delta^{13} \mathrm{C}_{\mathrm{org}}$ covariance inspired Rothman et al. (2003) to propose the existence of a large Neoproterozoic dissolved organic carbon pool (DOC) that was periodically remineralized, driving dynamic behavior in the isotopic composition of the dissolved inorganic carbon pool (DIC). However, the existence of a large DOC reservoir in Neoproterozoic oceans is inconsistent with carbon isotope records that show covariance in both the early Ediacaran Sheepbed Formation (Fig. 8; Johnston et al., 2013-in this issue) and
Cryogenian records in Mongolia (Johnston et al., 2012a). Johnston et al. (2012a) instead suggested that the lack of covariance in $\delta^{13} C_{\text {carb }}$ and $\delta^{13} \mathrm{C}_{\text {org }}$ could alternatively be explained by bulk organic carbon in TOC-lean samples being more prone to masking by detrital and migrated organic matter. It must also be pointed out that in some modern shallow water carbonate systems there is no systemic correlation between organic and carbonate carbon isotope values (Oehlert et al., 2012). Moreover, driving the Shuram excursion with the remineralization of a large DOC reservoir requires the consumption of many present atmospheres of oxygen (Bristow and Kennedy, 2008), which would have presumably resulted in an anoxic event and not the oxygenation event that is sought after to support the subsequent expansion of large, mobile animals. Thus, models that evoke a large DOC reservoir to explain the Shuram excursion lack both theoretical and empirical footing.

\subsubsection{Methane model for the Shuram excursion}

Following the scenario outlined by Schrag et al. (2002), Bjerrum and Canfield (2011) suggested that the Shuram excursion was driven by the release of methane to the oceans. Methanogenesis and methane oxidation can produce enriched $\delta^{13} C_{\text {org }}$ values and depleted $\delta^{13} \mathrm{C}_{\text {carb}}$, potentially consistent with data presented here (Figs. 8, 11). To sustain the formation of isotopically depleted $\delta^{13} C_{\text {carb }}$ in carbonates over millions to tens of million year timescales, Bjerrum and Canfield (2011) called on the generation and slow release of clathrate hydrates in an ocean with a large DOC reservoir. While the large DOC model is problematic for the reasons outlined above, methanogenesis and anaerobic methane oxidation may have played a central role in the generation of isotopically light pore fluids and the precipitation of authigenic carbonate.

\subsubsection{Authigenic carbonate model for the Shuram excursion}

Alongside the Paleoproterozoic, Neoproterozoic carbon isotope records host both the most negative and positive carbon isotope values in Earth history (Prokoph et al., 2008; Grotzinger et al., 2011). A satisfactory explanation for the Shuram negative carbon isotope excursion should explain both dynamic shifts to negative $\delta^{13} C_{\text {carb }}$ values and a carbon cycle with stable enriched $\delta^{13} \mathrm{C}_{\text {carb }}$ values. Schrag et al. (2013) proposed a model whereby both the extreme positive and transient negative carbon isotope excursions in the Proterozoic are related to the same phenomena, namely the waxing and waning of a large and isotopically depleted sink of carbon in authigenic carbonate. Authigenic carbonates exist today, but given the higher levels of modern $\mathrm{O}_{2}$, are likely much less formidable (by mass) than is possible in a low $\mathrm{O}_{2}$ Proterozoic environment (Higgins et al., 2009).

We define authigenic carbonate as any carbonate mineral that precipitates in situ at, or below, the sediment-water interface due to alkalinity production associated with anaerobic respiration. This carbonate can form as micritic cements, crystal fans growing in the sediment or at the sediment water interface, or as carbonate laminae within microbial mats. It can also be subsequently weathered and redeposited to form allochems of carbonate grainstone or micrite. The formation of authigenic carbonates is the result of alkalinity produced from the oxidation of reduced carbon compounds $\left(\mathrm{C}_{\mathrm{org}}\right.$ and $\mathrm{CH}_{4}$ ) under reducing conditions. Thus, the pore fluids from which authigenic carbonates precipitate are generally depleted in ${ }^{13} \mathrm{C}$, although authigenic carbonate can also be enriched in ${ }^{13} \mathrm{C}$ in regions of methanogenesis (Sivan et al., 2007). In the modern ocean, authigenic carbonates are widespread (Anderson and Dyrssen, 1987; Roberts and Aharon, 1994; Aller et al., 1996; Reimers et al., 1996; Zhu et al., 2002; Meister et al., 2007; Naehr et al., 2007), though generally restricted to zones of intense anaerobic respiration $\left(\mathrm{SO}_{4}, \mathrm{Fe}\right.$, $\mathrm{Mn}$ reduction) so their contribution to the global carbon budget is small. Generally, this is because the precipitation of authigenic carbonate is inhibited by the amount of $\mathrm{O}_{2}$ in seawater due to the acidity generated via oxidation of reduced compounds $\left(\mathrm{C}_{\mathrm{org}}, \mathrm{H}_{2} \mathrm{~S}, \mathrm{Fe}^{2+}\right)$. 
Throughout the Earth's history, however, changes in organic carbon cycling, atmospheric oxygen, and the concentrations of other electron acceptors ( $\left.\mathrm{Fe}(\mathrm{III}), \mathrm{SO}_{4}^{2-}\right)$ could have led to a greater abundance of authigenic carbonates in marine sediments (e.g., Higgins et al., 2009). Therefore, a dynamic global authigenic carbonate sink is consistent with observations of Paleoproterozoic and Neoproterozoic carbon isotope variability, and it may help explain periods of intense carbon isotope variability in the Phanerozoic (Schrag et al., 2013).

Utilizing this framework, prolonged intervals of extremely positive $\delta^{13} C_{\text {carb }}$ values (e.g. Halverson et al., 2005) could reflect a global DIC reservoir that is enriched by the widespread burial of isotopically depleted authigenic carbonate. Carbon isotope variability within a given stratigraphic section (or a sequence stratigraphic framework) may reflect not only changes in the fraction of organic carbon burial relative to carbonate carbon, but also changes in the size of the global authigenic carbonate sink and/or changes in the amount of isotopically distinct authigenic carbon (depleted/enriched relative to DIC) that is incorporated into locally precipitated carbonate. Large negative carbon isotope excursions could therefore be interpreted as Type 1 excursions, reflecting a crash in the global abundance of authigenic carbonate and resulting in seawater DIC values being drawn down towards mantle values, or Type 2 excursions, reflecting a local change in the relative abundance of carbonate precipitated in the water column versus authigenic carbonate produced in the near-surface sediments (Schrag et al., 2013). Importantly, both Type 1 and Type 2 excursions do not require a large change in the global oxygen and carbon cycles (Bristow and Kennedy, 2008), but may rather reflect an amplified local response to a modest global change during a period in the Earth's history with a large, dynamic authigenic carbonate sink. In addition, Type 1 and Type 2 excursions are not mutually exclusive, so a specific observation of a carbon isotope anomaly may have both global (Type 1) and local (Type 2) contributions.

The model presented here makes predictions for the scale and distribution of isotopically depleted carbonates in which their composition will reflect a mixture of authigenic carbonate formed in situ and that which is precipitated from the DIC of seawater that has diffused into porewaters. Carbonates produced in situ (like crystal fans or microbialites) should record variable mixtures of the $\delta^{13} \mathrm{C}_{\text {carb }}$ of pore fluids that are influenced by anaerobic remineralization and marine DIC. Like crystal fans and microbialites, the $\delta^{13} \mathrm{C}_{\text {carb }}$ composition of ooids may also be influenced by microenvironments created by microbial films (Duguid et al., 2010; Pacton et al., 2012; Edgcomb et al., 2013). The $\delta^{13} C_{\text {carb }}$ values of allochems such as carbonate grainstone may be complicated by the reworking of carbonate produced in surface waters separated from the authigenic cycle and those reworked from carbonate precipitated in situ.

On larger scales, the total volume and the stratigraphic thickness of authigenic carbonate is ultimately limited by organic carbon and electron acceptors used in anaerobic respiration (e.g., $\mathrm{Fe}(\mathrm{III}), \mathrm{SO}_{4}^{2-}$ ). By volume, thick carbonate successions will have less of these ingredients for carbonate authigenesis than siliciclastic successions. At any one time, authigenic carbonate is being created in the iron or sulfate reduction zone, which can be up to meters to many tens of meters thick (Sivan et al., 2007). Precipitation of authigenic carbonate can be focused in a particular region within the sediment column, creating a layer with very high carbonate content. But on the length scale of diffusion of DIC in the pore fluid (i.e., meters to tens of meters), there must be sufficient organic carbon and electron acceptors to drive the production of alkalinity and the carbon isotopic depletion of the pore fluid. A slight complication is authigenic carbonate precipitation driven by methanotrophy, where the location of organic carbon-rich sediments (and methanogenesis) can be physically removed from the location of methane oxidation. But in general, this suggests that the stratigraphic scale of Type 2 authigenic $\delta^{13} C_{\text {carb }}$ excursions should be limited to mixed carbonate-siliciclastic successions with authigenic carbonate forming high-carbonate layers no thicker than roughly $10 \mathrm{~m}$. In contrast, when isotopic excursions are observed in thick, carbonate-rich sequences (i.e., greater than $80 \%$ carbonate), it is more difficult to explain the carbon isotope variations as predominantly caused by local authigenic carbonate precipitation. It is theoretically possible that organic carbon was abundant but has since been oxidized, but one would still expect authigenic carbonate to be no more than $10 \%$ of the total sediment mass, averaged over tens of meters of sediment. Thus, isotope anomalies in carbonate-rich sequences are most likely explained by changes in the global carbon isotope budget (Type 1), and are likely to be more useful for chemostratigraphic correlations.

In Oman (Le Guerroue et al., 2006a), Australia (Calver, 2000), and Death Valley (Verdel et al., 2011), extremely negative carbonate $\delta^{13} \mathrm{C}_{\text {carb }}$ values $(<-8 \%$ ) of the Shuram excursion occur in mixed carbonate-siliciclastic successions. These $\delta^{13} \mathrm{C}$ data are from carbonate cements and thin carbonate beds that are interbedded with siliciclastic strata on a $\mathrm{cm}$ to $10 \mathrm{~m}$ scale. Where carbonate strata dominates more of the stratigraphic succession (on the 10 to $100 \mathrm{~m}$ scale), $\delta^{13} \mathrm{C}_{\text {carb }}$ values are still depleted, but closer to the range of plausible mantle values $(-8$ to $-4 \%$ ). Therefore, it is possible that the Shuram excursion records a mixture between isotopically depleted seawater and carbonate produced in situ. Furthermore, the diffusion of seawater DIC into the zone of authigenesis may account for the relative smoothness of the Shuram isotope excursion in carbonate dominated settings relative to typical authigenic cements formed in siliclastic-dominated settings. It has been suggested that the extremely depleted $\delta^{13} C_{\text {carb }}$ values represent seawater DIC because of a low degree of point-to-point isotopic variability and their expression in oolitic (and crystal fan) grainstone without evidence for secondary cement precipitation (Bergmann et al., 2011). However, textural preservation throughout the Shuram excursion only insures that alkalinity with low $\delta^{13} \mathrm{C}_{\mathrm{carb}}$ values was created very early and in close proximity to the sedimentwater interface.

\subsubsection{The Shuram-like Gametrail excursion in northwestern Canada}

In northwestern Canada, the nadir of the Gametrail excursion occurs in a TST and recovers gradually through an HST. Within the Sequence 2a TST in northwestern Canada, the Gametrail excursion displays an apparent lateral gradient from - 8.5\% in the Fog Camp and Goz B sections of the Wernecke Mountains to variable nadirs at only - 5\% at Goz A and Goz D (Fig. 8), and only to $-2 \%$ at Sekwi Brook (Figs. 5 \& 12). This could be due in part to variability in local carbonate production; however, in a sequence stratigraphic framework, this variability most likely reflects condensation of the TST in the deepest water sections and diachronous deposition on the shelf. Interestingly, syn-excursion values oscillate between -8.5 and $3.5 \%$ (Fig. 8) despite no obvious textural changes. These values are recorded through $10 \mathrm{~s}$ to 100 s of meters of predominantly pinkcolored, microbilaminated dolomite abound with evidence of in situ carbonate precipitation in the form of micritic to blocky cement between crinkly laminations. As outlined above, carbonate formed in situ may or may not be recording $\delta^{13} \mathrm{C}_{\text {carb }}$ composition of seawater. A petrographic determination of the abundance and percentage of carbonate formed via anaerobic respiration in the Gametrail Formation is limited not only by pervasive recrystallization, but also by the lack of constraints on the paleo-diffusion profile of DIC. Carbon isotope values from separate portions of individual hand samples are reproducible on an $\sim 1 \%$ scale, suggestive that the larger variability is on a meter- to decimeter-scale. The abundance of carbonate through the Gametrail excursion, which is typically $<10 \%$ siliciclastic content for $\sim 100 \mathrm{~m}$ of stratigraphy, suggests that authigenic carbonate production would have been limited by organic carbon and electron acceptors ( $\mathrm{Fe}(\mathrm{III}), \mathrm{SO}_{4}^{2-}$ ) and that the depleted values are not exclusively a product of local, in situ authigenic carbonate production. However, the most negative values, at Fog Camp and Goz B, rest above thick sequences of black shale, potentially providing a source for 
additional alkalinity production through anaerobic remineralization. Moreover, the pink, TOC-poor and iron-rich carbonates may have initially contained more organic matter that was anaerobically respired within the microbial mat. Again, in the Gametrail excursion, like Shuram excursions elsewhere, there is evidence for both a negative carbon isotope excursion in seawater and an anomaly from local carbonate production. Untangling the relative carbon isotopic contribution from both may be tricky.

The negative $\delta^{13} \mathrm{C}_{\text {carb }}$ values in the Blueflower Formation are more typical authigenic cements, where dolomite nodules within siliciclastic strata have $\delta^{13} \mathrm{C}_{\text {carb }}$ values down to $-12 \%$ (Fig. 8). These are likely more akin to the cements with highly depleted but scattered $\delta^{13} C_{\text {carb }}$ values in siliciclastic-dominated Ediacaran strata of South China (Li et al., 1999; Jiang et al., 2007) and the Tarim Block (Xiao et al., 2004). Carbonate is volumetrically minor within these successions and consequently their $\delta^{13} \mathrm{C}_{\text {carb }}$ values may not represent that of seawater DIC and they may not be coincident with a negative $\delta^{13} C_{\text {carb }}$ excursion in seawater. In fact, if these cements represent an increase in global authigenic carbonate burial they could alternatively have formed during a positive carbon isotope excursion in the DIC reservoir of seawater.

In this contribution we use sequence, bio-, and chemostratigraphy to construct an age model for Ediacaran strata, but then we discuss that some of the carbonates may be forming in situ without direct communication with the well-mixed DIC of seawater. Although this may seem to compromise our chemostratigraphic correlations, Schrag et al. (2013) noted that authigenic events are likely to be broadly correlative due to global changes in surface redox conditions, surface saturation state, and/or eustatic sea level, all of which might drive a migration of the zone of authigenesis or a change in the amount of authigenic precipitation. We suggest here that the carbon isotopic composition of seawater prior to the Shuram event was enriched, not because of high organic carbon burial, but instead through high authigenic carbonate burial. During the Shuram event, a crash in authigenic carbonate burial may have contributed to a global negative $\delta^{13} \mathrm{C}_{\text {carb }}$ excursion in seawater to values as low as mantle input, as seen in carbonate-dominated successions that span the Shuram excursion. This would also require that there was low fractional organic carbon burial during this time. Local alkalinity produced in concert with the Shuram excursion may have led to regional variability in the nadir of the Shuram excursion from -6 to $-12 \%$, but the volume of this local carbonate production had to be small to have maintained a reduced budget of global authigenic carbonate burial. A similar scenario has been proposed for Triassic-Jurassic boundary sections, which record a global negative $\delta^{13} C_{\text {carb }}$ excursion in seawater, but the magnitude of the excursion varies by as much as $4 \%$ between sections due to local carbonate production (Greene et al., 2012a, 2012b). In the case of the Shuram excursion, the extremely negative values are expressed most dramatically in siliciclastic settings, but carbonate dominated successions also host an excursion. Thus, we maintain that carbon isotopes chemostratigraphy is useful for correlation, particularly in carbonate dominated successions, but that local carbonate production can lead to regional variability particularly in siliciclastic dominated successions and is in part responsible for the variability we observe in the Shuram equivalent excursions.

An interesting corollary to the authigenic carbonate model presented above is the stratigraphic relationship to bioturbation. In northwestern Canada the first appearance of trace fossils occurs directly above the Gametrail excursion, which we suggest is correlative with the Shuram excursion. Globally, this is consistent with the appearance of abundant bioturbation at $\sim 555 \mathrm{Ma}$ in the White Sea region (Martin et al., 2000) during, or after, the pre-550 Ma Shuram excursion (Fig. 13). Negative carbon isotope excursions as extreme as the Shuram excursion do not occur later in Earth history (Grotzinger et al., 2011) and prolonged intervals of heavy background seawater $\delta^{13} \mathrm{C}_{\text {carb }}$ values are less common in the latest Ediacaran and
Phanerozoic (Halverson et al., 2005; Prokoph et al., 2008). The evolution of more complex feeding patterns and associated bioturbation likely increased the rate of aerobic remineralization of organic matter in marine sediments and supplied oxidants to otherwise anoxic pore waters (Aller, 1994; Ziebis et al., 1996; Mcllroy and Logan, 1999; Meysman et al., 2006; Canfield and Farquhar, 2009; Aller et al., 2010). This increase in aerobic respiration would have decreased anaerobic respiration pathways, and inhibited the precipitation of authigenic carbonate by increasing the acidity generated through the oxidation of reduced compounds $\left(\mathrm{C}_{\mathrm{org}}, \mathrm{H}_{2} \mathrm{~S}, \mathrm{Fe}^{2+}\right)$. Consequently, the expansion of bioturbation likely led to a decline in the authigenic carbonate sink.

\section{Conclusions}

Integrated sequence stratigraphic, chemostratigraphic, and biostratigraphic studies of Ediacaran strata in northwestern Canada demonstrate that sections at Sekwi Brook containing the FAD of Ediacara-type fossils rest above a major incised surface and are present in the June beds, which are not correlative with the Sheepbed Formation elsewhere and are thus much younger than sections with Fe-speciation data previously used to suggest a rise in oxygen (Shen et al., 2008). Further work is necessary to test if the Fe-speciation shift above the Gaskiers glacial deposits in Newfoundland (Canfield et al., 2007) can be reproduced globally (Johnston et al., 2012b) and if it is present in the June beds in northwestern Canada. A large onegative $\delta^{13} \mathrm{C}_{\text {carb }}$ excursion is variably preserved in a transgressive systems tract at the base of the Gametrail Formation, above Ediacaratype fossil impressions and directly below abundant bilaterian burrows. We propose that this Gametrail $\delta^{13} C_{\text {carb }}$ excursion is correlative to the Shuram excursion and that the location and amount of authigenic carbonate production played a role in the excursion. The expansion of bilaterian bioturbation likely led to increased aerobic respiration of organic matter in sediments and a concomitant decline in the authigenic carbonate sink.

Supplementary data to this article can be found online at http:// dx.doi.org/10.1016/j.chemgeo.2013.05.032.

\section{Acknowledgments}

We thank: the Yukon Geological Survey and the MIT NASA NAI node for support; Fireweed, Canadian, and TransNorth helicopters for safe transport; Charlie Roots and his family for their hospitality and logistical support; Sasha Breus, Greg Eischied, and Zhongxing Chen for assistance in the lab; Alan Rooney, Trevor Petach and Esther Kennedy for help in the field. GMN acknowledges support from a Discovery Grant from the Natural Sciences and Engineering Research Council of Canada (NSERC) and a Queen's University Research Chair. EAS is supported by an Agouron Postdoctoral Fellowship. We thank Rob MacNaughton and two anonymous reviewers for their critical and constructive reviews. We dedicate this manuscript to Dick Holland in memory of his productive time at Harvard University.

\section{References}

Abbott, G., 1997. Geology of the Upper Hart River Area, Eastern Ogilvie Mountains, Yukon Territory (116A/10,116A/11): Exploration and Geological Services Division, Yukon Region, Bulletin, 9, pp. 1-76.

Aitken, J.D., 1982. Precambrian of the Mackenzie Fold Belt - a stratigraphic and tectonic overview. In: Hutchinson, R.W., Spence, C.D., Franklin, J.M. (Eds.), Precambrian Sulphide Deposits. Geological Association of Canada, Ontario, pp. 150-161.

Aitken, J.D., 1984. Strata and trace fossils near the Precambrian-Cambrian boundary, Mackenzie, Selwyn and Wernecke mountains, Yukon and Northwest Territories: discussion. Current Research, Part B, Geological Survey of Canada, Paper 84-1B, pp. 401-407.

Aitken, J.D., 1989. Uppermost Proterozoic formations in central Mackenzie Mountains, Northwest Territories. Geological Survey of Canada Bulletin 368, 1-26. 
Aitken, J.D., 1991a. The Ice Brook Formation and Post-Rapitan, Late Proterozoic glaciation, Mackenzie Mountains, Northwest Territories. Geological Survey of Canada Bulletin 404, 1-43.

Aitken, J.D., 1991b. Two late Proterozoic glaciations, Mackenzie Mountains, northwestern Canada. Geology 19 (5), 445-448.

Allen, P.A., Hoffman, P.F., 2005. Extreme winds and waves in the aftermath of Neoproterozoic glaciation. Nature 433, 123-127.

Aller, R.C., 1994. Bioturbation and remineralization of sedimentary organic matter: effects of redox oscillation. Chemical Geology 114 (3-4), 331-345.

Aller, R.C., Blair, N.E., Xia, Q., Rude, P.D., 1996. Remineralization rates, recycling and storage of carbon in Amazon shelf sediments. Continental Shelf Research 16 , 753.

Aller, R.C., Madrid, V., Chistoserdov, A., Aller, J.Y., Heilbrun, C., 2010. Unsteady diagenetic processes and sulfur biogeochemistry in tropical deltaic muds: implications for oceanic isotope cycles and the sedimentary record. Geochimica et Cosmochimica Acta 74 (16), 4671-4692.

Amthor, J.E., et al., 2003. Extinction of Cloudina and Namacalathus at the PrecambrianCambrian boundary in Oman. Geology 31 (5), 431-434.

Anderson, L.G., Dyrssen, D., 1987. Formation of chemogenic calcite in super-anoxic seawater-Framvaren, southern Norway. Marine Chemistry 20 (4), 361-376.

Banner, J.L., Hanson, G.N., 1990. Calculation of simultaneous isotopic and trace element variations during water-rock interaction with application to carbonate diagenesis. Geochimica et Cosmochimica Acta 54, 3123-3137.

Bergmann, K.D., Zentmyer, R.A., Fischer, W.W., 2011. The stratigraphic expression of a large negative carbon isotope excursion from the Ediacaran Johnnie Formation, Death Valley. Precambrian Research 188, 45-56

Bjerrum, C.J., Canfield, D., 2011. Towards a quantitative understanding of the late Neoproterozoic carbon cycle. Proceedings of the National Academy of Science 108 (14), 5542-5547.

Bond, G.C., Kominz, M.A., 1984. Construction of tectonic subsidence curves for the early Paleozoic miogeocline, southern Canadian Rocky Mountains: implications for subsidence mechanisms, age of breakup, and crustal thinning. Geological Society of America Bulletin 95 (2), 155-173.

Bond, G.C., Kominz, M.A., Devlin, W.J., 1983. Thermal subsidence and eustasy in the Lower Palaeozoic miogeocline of western North America. Nature 306, 775-779.

Bowring, S.A., et al., 1993. Calibrating rates of Early Cambrian evolution. Science 261 (5126), 1293-1298.

Bowring, S.A., Myrow, P.M., Landing, E., Ramezani, J., 2003. Geochronological constraints on terminal Neoproterozoic events and the rise of metazoans. Geophysical Research Abstracts 5, 219.

Bowring, S.A., Grotzinger, J.P., Condon, D.J., Ramezani, J., Newall, M., 2007. Geochronologic constraints on the chronostratigraphic framework of the Neoproterozoic Huqf Supergroup, Sultanate of Oman. American Journal of Science 307, $1097-1145$.

Bristow, T.F., Kennedy, M.J., 2008. Carbon isotope excursions and the oxidant budget of the Ediacaran atmophere and ocean. Geology 36 (11), 863-866.

Burns, S.J., Matter, A., 1993. Carbon isotopic record of the latest Proterozoic from Oman. Eclogae Geologicae Helvetiae 86 (2), 595-607.

Calver, C.R., 2000. Isotope stratigraphy of the Ediacaran (Neoproterozoic III) of the Ad elaide Rift Complex, Australia, and the overprint of water column stratification. Precambrian Research 100, 121-150.

Canfield, D.E., Farquhar, J., 2009. Animal evolution, bioturbation, and the sulfate concentration of the oceans. Proceedings of the National Academy of Sciences 106 (20), 8123-8127.

Canfield, D., Poulton, S.W., Narbonne, G.M., 2007. Late-Neoproterozoic deep-ocean oxygenation and the rise of animal life. Science 315 (5808), 92-95.

Cecile, M.P., 2000. Geology of the northeastern Niddery Lake map area, east central Yukon and adjacent Northwest Territories. Geological Survey of Canada Bulletin $553,120$.

Colpron, M., 2012. Preliminary observations on the geology of the Rackla belt, Mount Ferrell map area (NTS 106C/3), central Yukon. In: MacFarlane, K.E., Sack, P.J. (Eds.), Yukon Exploration and Geology 2011. Yukon Geological Survey, Whitehorse, Yukon, pp. 27-43

Colpron, M., Logan, J.M., Mortensen, J.K., 2002. U-Pb zircon age constraint for late Neoproterozoic rifting and initiation of the lower Paleozoic passive margin of western Laurentia. Canadian Journal of Earth Sciences 39, 133-143.

Condon, D.J., et al., 2005. U-Pb ages from the Neoproterozoic Doushantuo Formation, China. Science 308, 95-98.

Conway Morris, S., Fritz, W.H., 1980. Shelly microfossils near the Precambrian-Cambrian boundary, Mackenzie Mountains, northwestern Canada. Nature 286 (5771), 381-384.

Corsetti, F.A., Hagadorn, J.W., 2000. Precambrian-Cambrian transition: Death Valley, United States. Geology 28 (4), 299-302.

Corsetti, F.A., Kaufman, A.J., 2003. Stratigraphic investigations of carbon isotope anomalies and Neoproterozoic ice ages in Death Valley, California. Geological Society of America Bulletin 115 (8), 916-932.

Dalrymple, R.W., Narbonne, G.M., 1996. Continental slope sedimentation in the Sheepbed Formation (Neoproterozoic Windermere Supergroup), Mackenzie Mountains, N.W.T. Canadian Journal of Earth Sciences 33, 848-862.

Derry, L.A., 2010. A diagenetic origin for the Ediacaran Shuram-Wonoka carbon isotope anomaly. Earth and Planetary Science Letters 294, 152-162.

Duguid, S.M.A., Kyser, T.K., James, N.P., Rankey, E.C., 2010. Microbes and ooids. Journal of Sedimentary Research 80, 236-251.

Edgcomb, V., et al., 2013. Molecular indicators of microbial diversity in oolitic sands of Highborne Cay, Bahamas. Geobiology 11 (3), 234-251.
Eisbacher, G.H., 1981. Sedimentary tectonics and glacial record in the Windermere Supergroup, Mackenzie Mountains, northwestern Canada. Geological Survey of Canada Paper 80-27, 1-40.

Fike, D.A., Grotzinger, J.P., Pratt, L.M., Summons, R.E., 2006. Oxidation of the Ediacaran Ocean. Nature 444, 744-747.

Finnegan, S., Fike, D.A., Jones, D., Fischer, W.W., 2012. A temperature-dependent positive feedback on the magnitude of carbon isotope excursions. Geoscience Canada 39 (3).

Foden, J., Barovich, K.M., O'Halloran, M., 2001. Sr-isotopic evidence for Late Neoproterozoic rifting in the Adelaide geosyncline at $586 \mathrm{Ma}$ : implications for a Cu ore forming fluid flux. Precambrian Research 106, 291-308.

Fritz, W.H., Narbonne, G.M., Gordey, S.P., 1983. Strata and trace fossils near the Precambrian Cambrian Boundary, Mackenzie, Selwyn, and Wernecke Mountains, Yukon and Northwest Territories. Current Research, Part B, Geological Survey of Canada, Paper 83-1B, pp. 365-375.

Gabrielse, H., Blusson, S.L., Roddick, J.A., 1973. Geology of Flat River, Glacier Lake and Wrigley Lake map-areas. District of Mackenzie and Yukon Territory, Geological Survey of Canada, Memoir 366.

Gehling, J.G., 2007. Fleshing out the Ediacaran Period. In: Vickers-Rich, P., Komarower, P. (Eds.), The Rise and Fall of Ediacaran Biota. Geological Society of London Special Publications, London, pp. 425-428.

Gehling, J.G., Droser, M.L., 2013. How well do fossil assemblages of the Ediacara biota tell time? Geology 41 (4), 447-450.

Gehling, J.G., Narbonne, G.M., Anderson, M.A., 2000. The first named Ediacaran body fossil, Aspidella terranovica. Palaentology 43, 427-456.

Gensel, P.G., 2008. The earliest land plants. Annual Review of Ecological and Evolutionary Systems 39, 459-477.

Gordey, S.P., Anderson, R.G., 1993. Evolution of the northern Cordillera miogeocline, Nahanni map area (105 I) Yukon and Northwest Territories. Geological Survey of Canada Memoir 428, 214.

Gostin, V.A., McKirdy, D.M., Webster, L.J., Williams, G.E., 2010. Ediacaran ice-rafting and coeval asteroid impact, South Australia: insights into the terminal Proterozoic environment. Australian Journal of Earth Sciences 57 (7), 859-869.

Greene, S.E., Bottjer, D.J., Corsetti, F.A., Berelson, W.M., Zonneveld, J.P., 2012a. A subseafloor carbonate factory across the Triassic-Jurassic transition. Geology 40 (11), 1043-1046

Greene, S.E., et al., 2012b. Recognising ocean acidification in deep time: an evaluation of the evidence for acidification across the Triassic-Jurassic boundary. Earth-Science Reviews 113, 72-93.

Grotzinger, J.P., Bowring, S.A., Saylor, B.Z., Kaufman, A.J., 1995. Biostratigraphic and geochronologic constraints on early animal evolution. Science 270 (5236), 598-604.

Grotzinger, J.P., Fike, D.A., Fischer, W.W., 2011. Enigmatic origin of the largest-known carbon isotope excursion in Earth's history. Nature Geoscience 4, 285-292.

Halverson, G.P., Hoffman, P.F., Schrag, D.P., Maloof, A.C., Rice, A.H.N., 2005. Toward a Neoproterozoic composite carbon-isotope record. Geological Society of America Bulletin 117 (9-10), 1181-1207.

Halverson, G.P., Dudás, F.O., Maloof, A.C., Bowring, S.A., 2007. Evolution of the ${ }^{87} \mathrm{Sr} /{ }^{86} \mathrm{Sr}$ composition of Neoproterozoic seawater. Palaeogeography, Palaeoclimatology, Palaeoecology 256, 103-129.

Hayes, J.M., Strauss, H., Kaufman, A.J., 1999. The abundance of 13C in marine organic matter and isotopic fractionation in the global biogeochemical cycle of carbon during the past $800 \mathrm{Ma}$. Chemical Geology 161 (1-3), 103-125.

Higgins, J.A., Fischer, W.W., Schrag, D.P., 2009. Oxygenation of the ocean and sediments: Consequences for the seafloor carbonate factory: Earth and Planetary Science Letters, v. 284, no. 1-2, pp. 25-33.

Hoffman, P.F., Halverson, G.P., 2011. Neoproterozoic glacial record in the Mackenzie Mountains, northern Canadian Cordillera. In: Arnaud, E. Halverson, G.P. ShieldsZhou, G. (Eds.), The Geological Record of Neoproterozoic Glaciations. The Geological Society, London, pp. 397-412.

Hoffman, P.F., Macdonald, F.A., 2010. Sheet-crack cements and early regression in Marinoan (635 Ma) cap dolostones: regional benchmarks of vanishing icesheets? Earth and Planetary Science Letters 300, 374-384.

Hoffman, P.F., et al., 2007. Are basal Ediacaran (635 Ma) post-glacial "cap dolostones" diachronous? Earth and Planetary Science Letters 258, 114-131.

Hoffman, P.F., Macdonald, F.A., Halverson, G.P., 2011. Chemical sediments associated with Neoproterozoic glaciation: iron formation, cap carbonate, barite and phosphorite. In: Arnaud, E. Halverson, G.P. Shields, G. (Eds.), The Geologic Record of Neoproterozoic Glaciations. Geological Society of London, London, pp. 67-80.

Hoffmann, K.H., Condon, D.J., Bowring, S.A., Crowley, J.L., 2004. U-Pb zircon date from the Neoproterozoic Ghaub Formation, Namibia: constraints on Marinoan glaciation. Geology 32, 817-820.

Hofmann, H.J., Narbonne, G.M., Aitken, J.D., 1990. Ediacaran remains from intertillite beds in northwestern Canada. Geology 18, 1199-1202.

Husson, J.M., Maloof, A.C., Schoene, B., 2012. A syn-depositional age for Earth's deepest $\delta^{13} \mathrm{C}$ excursion required by isotope conglomerate tests. Terra Nova 24 (4), $318-325$

Irwin, H., Curtis, C., Coleman, M., 1977. Isotopic evidence for source of diagenetic carbonates formed during burial of organic-rich sediments. Nature 269, 209-213.

James, N.P., Narbonne, G.M., Kyser, T.K., 2001. Late Neoproterozoic cap carbonates: Mackenzie Mountains, northwestern Canada: precipitation and global glacial meltdown. Canadian Journal of Earth Sciences 38 (8), 1229-1262.

Jefferson, C.W., Parrish, R., 1989. Late Proterozoic stratigraphy, U/Pb zircon ages and rift tectonics, Mackenzie Mountains, northwestern Canada. Canadian Journal of Earth Sciences 26, 1784-1801.

Jiang, G., Kaufman, A.J., Christie-Blick, N., Zhang, S., Wu, H., 2007. Carbon isotope variability across the Ediacaran Yangtze platform in South China: implications for a 
large surface-to-deep ocean $\delta^{13} \mathrm{C}$ gradient. Earth and Planetary Science Letters 261, 303-320.

Johnston, D.T., Macdonald, F.A., Gill, B., Hoffman, P.F., Schrag, D.P., 2012a. Uncovering the Neoproterozoic carbon cycle. Nature 483 (7389), 320-323.

Johnston, D.T., et al., 2012b. Late Ediacaran redox stability and metazoan evolution. Earth and Planetary Science Letters (335-336), 25-35.

Johnston, D.T., et al., 2013. Searching for an oxygenation event in the fossiliferous Ediacaran of northwestern Canada. Chemical Geology 362, 273-286 (in this issue).

Kaufman, A.J., Jacobsen, S.B., Knoll, A.H., 1993. The Vendian record of Sr and C isotopic variations in seawater; implications for tectonics and paleoclimate. Earth and Planetary Science Letters 120 (3-4), 409-430.

Kaufman, A.J., Knoll, A.H., Narbonne, G.M., 1997. Isotopes, ice ages, and terminal Proterozoic Earth history. Proceedings of the National Academy of Sciences 95, 6600-6605.

Kaufman, A.J., Jiang, G., Christie-Blick, N., Banerjee, D.M., Vibhuti, R., 2006. Stable isotope record of the terminal Neoproterozoic Krol platform in the Lesser Himalayas of northern India. Precambrian Research 147, 156-185.

Knauth, P.L., Kennedy, M.J., 2009. The late Precambrian greening of the Earth. Nature 460, 728-732.

Knoll, A.H., Grotzinger, J.P., Kaufman, A.J., Kolosov, P., 1995. Integrated approaches to terminal Proterozoic stratigraphy: an example from the Olenek uplift, northeastern Siberia. Precambrian Research 73, 251-270.

Knoll, A.H., Walter, M.R., Narbonne, G.M., Christie-Blick, N., 2006. The Ediacaran Period: a new addition to the geologic time scale. Lethaia 39 (1), 13-30.

Le Guerroue, E., Allen, P.A., Cozzi, A., 2006a. Chemostratigraphic and sedimentological framework of the largest negative carbon isotopic excursion in Earth history: the Neoproterozoic Shuram Formation (Nafun Group, Oman). Precambrian Research 146, 68-92.

Le Guerroue, E., Allen, P.A., Cozzi, A., Etienne, J.L., Fanning, M., 2006b. 50 Myr recovery from the largest negative $813 \mathrm{C}$ excursion in the Ediacaran ocean. Terra Nova 18 (2), 147-153

Li, R., et al., 1999. Spatial and temporal variations in carbon and sulfur isotopic compositions of Sinian sedimentary rocks in the Yangtze platform, South China. Precambrian Research 97, 59-75.

Macdonald, F.A., Cohen, P.A., 2011. The Tatonduk inlier, Alaska-Yukon border. In: E., A., Halverson, G.P., Shields-Zhou, G. (Eds.), The Geological Record of Neoproterozoic Glaciations. Geological Society of London, London, pp. 389-396.

Macdonald, F.A., McClelland, W.C., Schrag, D.P., Macdonald, W.P., 2009. Neoproterozoic glaciation on a carbonate platform margin in Arctic Alaska and the origin of the North Slope subterrane. Geological Society of America Bulletin 121, 448-473.

Macdonald, F.A., et al., 2010. Calibrating the Cryogenian. Science 327, 1241-1243.

Macdonald, F.A., et al., 2011. Neoproterozoic and early Paleozoic correlations in the western Ogilvie Moutnains, Yukon. In: MacFarlane, K.E., Weston, L.H., Relf, C. (Eds.), Yukon Exploration and Geology 2010. Yukon Geological Survey, Whitehorse, pp. 161-182.

MacNaughton, R.B., Narbonne, G.M., 1999. Evolution and ecology of NeoproterozoicLower Cambrian trace fossils, NW Canada. Palaios 14 (2), 97-115.

MacNaughton, R.B., Narbonne, G.M., Dalrymple, R.W., 2000. Neoproterozoic slope deposits, Mackenzie Mountains, northwestern Canada: implications for passivemargin development and Ediacaran faunal ecology. Canadian Journal of Earth Sciences 37 (7), 997-1020

MacNaughton, R.B., Roots, C.F., Martel, E., 2008. Neoproterozoic-(?)Cambrian lithostratigraphy, northeast Sekwi Mountain map area, Mackenzie Mountains, Northwest Territories: new data from measured sections. Geological Society of Canada, Current Research 16, 1-17.

Geology of the central Mackenzie Mountains of the northern Canadian Cordillera, Sewki Mountain (105P), Mount Eduni (106A), and northwestern Wrigley Lake (95 M) map-areas, Northwest Territories. In: Martel, E., Turner, E.C., Fischer, B.J. (Eds.), NWT Special Volume, 1. NWT Geoscience Office, Yellowknife, CA (423 pp.).

Martin, M.W., Grazhdankin, D.V., Bowring, S.A., Fedonkin, M.A., Kirschvink, J.L., 2000. Age of Neoproterozoic bilatarian body and trace fossils, White Sea, Russia: implications for metazoan evolution. Science 288 (5467), 841-845.

McFadden, K.A., et al., 2008. Pulsed oxidation and biological evolution in the Ediacaran Doushantuo Formation. Proceedings of the National Academy of Sciences 105 (9), 3197-3202.

Mcllroy, D., Logan, G.A., 1999. The impact of bioturbation on infaunal ecology and evolution during the Proterozoic-Cambrian transition. Palaios 14 (1), 58-72.

Meister, P., et al., 2007. Dolomite formation in the dynamic deep biosphere: results from the Peru margin. Sedimentology 54, 1007-1031.

Melezhik, V.A., Pokrovskii, B.G., Fallick, A.E., Kuznetsov, A.B., Bujakaite, M.I., 2009. Constraints on ${ }^{87} \mathrm{Sr} /{ }^{86} \mathrm{Sr}$ of Late Ediacaran seawater: insight from Siberian high-Sr limestones. Journal of the Geological Society of London 166, 183-191.

Melim, L.A., Swart, P.K., Maliva, R., 2001. Meteoric and marine burial diagenesis. In: Ginsberg, R.N. (Ed.), Subsurface Geology of a Prograding Carbonate Platform Margin. : Great Bahama Bank: Results of the Bahamas Drilling Project. SEPM Special Publication, Tulsa.

Meysman, F.J.R., Middelburg, J.J., Heip, C.H.R., 2006. Bioturbation: a fresh look at Darwin's last idea. Trends in Ecology \& Evolution 21 (12), 688-695.

Mitchum Jr., R.M., Van Wagoner, J.C., 1991. High-frequency sequences and their stacking patterns: sequence stratigraphic evidence for high-frequency eustatic cycles. Sedimentary Geology 70, 131-160.

Mustard, P.S., Roots, C.F., 1997. Rift-related volcanism, sedimentation, and tectonic setting of the Mount Harper Group, Ogilvie Mountains, Yukon Territory. Geological Survey of Canada Bulletin 492, 92.

Mustard, P.S., Donaldson, J.A., Thompson, R.I., 1988. Trace fossils and stratigraphy of the Precambrian-Cambrian boundary sequence, upper Harper group, Ogilvie
Mountains, Yukon. Current Research, Part E: Geological Survey of Canada Paper 88-1E, pp. 197-203.

Naehr, T.H., et al., 2007. Authigenic carbonate formation at hydrocarbon seeps in continental margin sediments: a comparative study. Deep Sea Research II 54, 1268-1291.

Narbonne, G.M., 1994. New Ediacaran (Neoproterozoic) fossils from northwestern Canada. Journal of Paleontology 68, 411-416.

Narbonne, G.M., Aitken, J.D., 1990. Ediacaran fossils from the Sekwi Brook area, Mackenzie Mountains, northwest Canada. Palaentology 33 (4), 945-980.

Narbonne, G.M., Aitken, J.D., 1995. Neoproterozoic of the Mackenzie Mountains, northwestern Canada. Precambrian Research 73, 101-121.

Narbonne, G.M., Gehling, J.G., 2003. Life after snowball: the oldest complex Ediacaran fossils. Geology 31 (1), 27-30.

Narbonne, G.M., Hofmann, H.J., 1987. Ediacaran biota of the Wernecke Mountains, Yukon, Canada. Palaeontology 30, 647-676.

Narbonne, G.M., Kaufman, A.J., Knoll, A.H., 1994. Integrated chemostratigraphy and biostratigraphy of the Windermere Supergroup, northwestern Canada: implications for Neoproterozoic correlations and the early evolution of animals. Geological Society of America Bulletin 106, 1281-1291.

Narbonne, G.M., Xiao, S., Shields-Zhou, G., 2012. Ediacaran period. In: Gradstein, F. Ogg, J., Schmitz, M.D., G., O. (Eds.), Geologic Timescale 2012. Elsevier, Oxford, pp. 427-449.

Nowlan, G.S., Narbonne, G.M., Fritz, W.H., 1985. Small shelly fossils and trace fossils near the Precambrian Cambrian boundary in the Yukon Territory, Canada. Lethiaia $18,233-256$.

Oehlert, A.M., et al., 2012. The stable carbon isotopic composition of organic material in platform derived sediments: implications for reconstructing the global carbon cycle. Sedimentology 59 (1), 319-335.

Osborne, D.T., Narbonne, G.M., Carrick, J., 1986. Stratigraphic and economic potential of Precambrian-Cambrian boundary strata, Wernecke Mountains, east-central Yukon. Yukon Geology 1, 131-138.

Pacton, M., et al., 2012. Going nano: a new step toward understanding the processes governing freshwater ooid formation. Geology 40 (6), 547-550.

Pell, S.D., McKirdy, D.M., Jansyn, J., Jenkins, R.J.F., 1993. Ediacaran carbon isotope stratigraphy of South Australia-an initial study. Transactions of the Royal Society of South Australia 117, 153-161.

Pokrovskii, B.G., Melezhik, V.A., Bujakaite, M.I., 2006. Carbon, oxygen, strontium, and sulfur isotopic compositions in Late Precambrian rocks of the Patom Complex, central Siberia: communication 1. Results, isotope stratigraphy, and dating problems. Lithology and Mineral Resources 41 (5), 450-474.

Prokoph, A., Shields, G.A., Veizer, J., 2008. Compilation and time-series analysis of a marine carbonate $\delta^{18} \mathrm{O}, \delta^{13} \mathrm{C},{ }^{87} \mathrm{Sr} /{ }^{86} \mathrm{Sr}$ and $\delta^{34} \mathrm{~S}$ database through Earth history. EarthScience Reviews 87, 113-133.

Pyle, L.J., Narbonne, G.M., James, N.P., Dalrymple, R.W., Kaufman, A.J., 2004. Integrated Ediacaran chronostratigraphy, Wernecke Mountains, northwestern Canada. Precambrian Research 132, 1-27.

Pyle, L.J., Narbonne, G.M., Nowlan, G.S., Xiao, S., James, N.P., 2006. Early Cambrian metazoan eggs, embryos, and phosphatic microfossils from northwestern Canada. Journal of Paleontology 80 (5), 811-825.

Reimers, C.E., Ruttenberg, K.C., Canfield, D.E., Christiansen, M.B., Martin, J.B., 1996 Porewater $\mathrm{pH}$ and authigenic phases formed in the uppermost sediments of the Santa Barbara Basin. Geochimica et Cosmochimica Acta 60 (21), 4037-4057.

Rice, A.H.N., Edwards, M.B., Hansen, T.A., Arnaud, E., Halverson, G.P., 2011. Glaciogenic rocks of the Neoproterozoic Smalfjord and Mortensnes formations, Vestertana Group, E. Finnmark, Norway. In: Arnaud, E., Halverson, G.P., Shields-Zhou, G. (Eds.), The Geological Record of Neoproterozoic Glaciations. Geological Society of London, London.

Roberts, H.H., Aharon, P., 1994. Hydrocarbon-derived carbonate buildups of the northern Gulf of Mexico continental slop: a review of submersible investigations. GeoMarine Letters 14 (2-3), 135-148.

Rothman, D.H., Hayes, J.M., Summons, R.E., 2003. Dynamics of the Neoproterozoic carbon cycle. Proceedings of the National Academy of Sciences 100, 8124-8129.

Sanderson, M.J., 2003. Molecular data from 27 proteins do not support a Precambrian origin of land plants. American Journal of Botany 90, 954-956.

Sawaki, Y., et al., 2010. The Ediacaran radiogenic Sr isotope excursion in the Doushantuo Formation in the Three Gorges area, South China. Precambrian Research $176,46-64$

Schlager, W., Reijmer, J.J.G., Droxler, A., 1994. Highstand shedding of carbonate platforms. Journal of Sedimentary Research B64, 270-281.

Schmitz, M.D., 2012. Radiometric ages used in GTS2012, Appendix 2. In: Gradstein, F., Ogg, J., Schmitz, M.D., Ogg, G. (Eds.), Geologic Timescale 2012. Elsevier, pp. 1045-1082.

Schrag, D.P., Berner, R.A., Hoffman, P.F., Halverson, G.P., 2002. On the initiation of snowball Earth. Geochemistry, Geophysics, Geosystems 3.

Schrag, D.P., Higgins, J.A., Macdonald, F.A., Johnston, D.T., 2013. Authigenic carbonate and the history of the global carbon cycle: Science, v. 339, pp. 540-543.

Shen, Y., Zhang, T., Hoffman, P.F., 2008. On the co-evolution of Ediacaran ocean and animals. Proceedings of the National Academy of Sciences 105 (21), 7376-7381.

Shen, B., et al., 2011. Carbon, sulfur, and oxygen isotope evidence for a strong depth gradient and ocean oxidation after the Hankalchough glaciation. Geochimica et Cosmochimica Acta $75,1357-1373$

Sivan, O., Schrag, D.P., Murray, R.W., 2007. Rates of methanogenesis and methanotrophy in deep-sea sediments. Geobiology 5 (2), 141-151.

Southgate, P.N., 1989. Relationships between cyclicity and stromatolite form in the Late Proterozoic Bitter Springs Formation, Australia. Sedimentology 36, 323-339. 
Spence, G.H., Tucker, M.E., 1997. Genesis of limestone megabreccias and their significance in carbonate sequence stratigraphic models: a review. Sedimentary Geology $112,163-193$

Stanley, S.M., 2010. Relation of Phanerozoic stable isotope excursions to climate, bacterial metabolism, and major extinctions. Proceedings of the National Academy of Sciences 107 (45), 19185-19189.

Swart, P.K., Kennedy, M.J., 2012. Does the global stratigraphic reproducibility of $\delta^{13} \mathrm{C}$ in Neoproterozoic carbonates require a marine origin? A Pliocene-Pleistocene comparison. Geology 40 (1), 87-90.

Tahata, M., et al., 2013. Carbon and oxygen isotope chemostratigraphies of the Yangtze platform, South China: decoding temperature and environmental changes through the Ediacaran. Gondwana Research 23, 333-353.

Thompson, R.I., Roots, C.F., Mustard, P.S., 1994. Geology of Dawson map area (116B, C, northeast of Tintina Trench). Geological Survey of Canada, Open File 2849.

Thorkelson, D.J., 2000. Geology and mineral occurrences of the Slats Creek, Fairchild Lake and "Dolores Creek" areas, Wernecke Mountains, Yukon Territory (106D/16, 106C/13, 106C/14). Exploration and Geological Services Division, Yukon Region, Bulletin 10.

Turner, E.C., et al., 2011. Chapter 3. Stratigraphy. In: Martel, E., Turner, E.C., Fischer, B. (Eds.), Geology of the Central Mackenzie Mountains of the Northern Canadian Cordillera, Sekwi Mountain (105P), Mount Eduni (106A), and Northwestern
Wrigley Lake (95M) Map-Areas, Northwest Territories. NWT Geoscience Office, Yellowknife, pp. 31-192.

Vandeginste, V., et al., 2005. Zebra dolomitization as a result of focused fluid flow in the Rocky Mountains Fold and Thrust Belt, Canada. Sedimentology 52, 1067-1095.

Verdel, C., Wernicke, B.P., Bowring, S.A., 2011. The Shuram and subsequent Ediacaran carbon isotope excursions from southwest Laurentia, and implications for environmental stability during the metazoan radiation. Geological Society of America Bulletin 123 (7-8), 1539-1559.

Xiao, S., Laflamme, M., 2009. On the eve of animal radiation: phylogeny, ecology and evolution of the Ediacaran biota. Trends in Ecology \& Evolution 24, 31-40.

Xiao, S., et al., 2004. The Neoproterozoic Quruqtagh Group in eastern Chinese Tianshan: evidence for a post-Marinoan glaciation. Precambrian Research 130, 1-26.

Zhou, C., Xiao, S., 2007. Ediacaran $\delta^{13} \mathrm{C}$ chemostatigraphy of South China. Chemical Geology 237, 107-126.

Zhu, Z., Aller, R.C., Mak, J., 2002. Stable carbon isotope cycling in mobile coastal muds of Amapa, Brazil. Continental Shelf Research 22, 2065-2079.

Ziebis, W., Forster, S., Huettel, M., Jorgensen, B.B., 1996. Complex burrows of the mud shrimp Callianassa truncata and their geochemical impact in the sea bed. Nature 382, 619-622.

Zimmer, A., et al., 2007. Dating the early evolution of plants: detection and molecular clock analyses of orthologs. Molecular Genetics and Genomics 278, 393-402. 